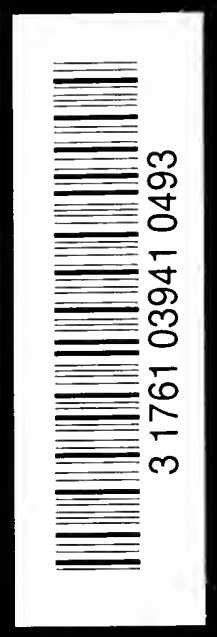






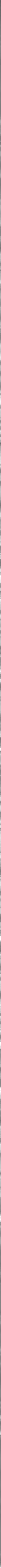




\section{Digitized by the Internet Archive in 2007 with funding from Microsoft Corporation}




\title{
SOME PROBLEMS IN \\ MARKET DISTRIBUTION
}

\author{
BY \\ ARCH WILKINSON SHAW, A.M. \\ LECTURER ON BUSINESS POLICY IN \\ HARVARD UNIVERSITY \\ EDITOR OF "SYSTEM"
}
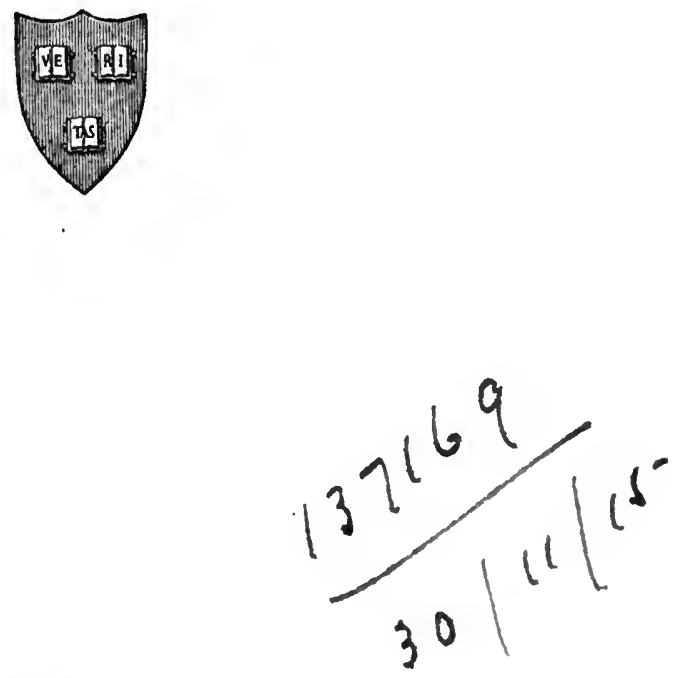

\section{CAMBRIDGE}

HARVARD UNIVERSITY PRESS

1915 
COPYRIGHT, 1915

BY

A. W. SHAW

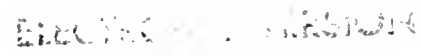

AVALAB

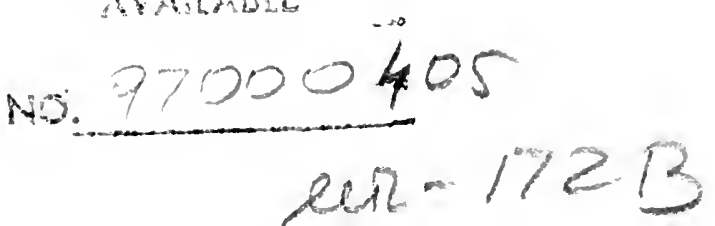




\section{FOREWORD}

This reprint of "Some Problems in Market Distribution" from the Quarterly Journal of Economics for August, 1912, I am preceding with an introductory chapter, "The Nature and Relations of Business Activities."

As all the activities of business are interdependent and all the problems of business arise out of the relations of these interdependent activities, this added matter may aid the reader by placing the activities of distribution in their relation to all the other activities of business.

Many of the ideas and even the forms of expression in this small book have come from those with whom I have been associated at Harvard University and in the editorial offices of the magazines System and Factory.

It would be difficult to make an adequate statement of my obligation to Dean Edwin Francis Gay of the Graduate School of Business Administration, Harvard University. Without his coöperation-and $I$ use the word in its broadest meaning - this book and the larger one, An Approach to Business Problems, soon to follow it, could hardly have been possible. 
is 


\section{SOME PROBLEMS IN MARKET DISTRIBUTION}




\section{SOME PROBLEMS IN MARKET DISTRIBUTION $^{1}$}

\section{CHAPTER I}

\section{THE NATURE AND RELATION OF BUSINESS ACTIVITIES}

UNTIL recently business has developed largely on an empirical basis, though there is a general healthy feeling abroad that the business man should approach his problems in the scientific spirit and should have exact information to guide him in meeting and settling them. To that end, departments for the gathering, classification and interpreting of statistics have been organized by many concerns, physical laboratories have been established for research work and tests of materials, and special staffs of trained men are maintained to study every operation and process involved in the business and to find and apply the most efficient known way of performing each. The standards thus determined serve not only as internal economies of the individual houses conducting the inquiries, but in many instances have become the external economies of entire industries.

1 The last three chapters of this book are reprinted from the Quarterly Journal of Economics, for August, 1912, published by Harvard University. 


\section{MARKET DISTRIBUTION}

The individual business has gone farthest in this gathering of information and standardizing of methods. Records are kept not only of important activities but of the details which influence costs, rate of production, ease in selling and similar vital matters. Comparative analyses and tabulations make clear the relations between each of these factors and the main purpose of the business, and guide the management in determining the policies to be followed. The facts and conclusions reached have seldom been collated, however, with like results attained by other concerns. The data on which any general scheme of standardization might be based usually have been considered business secrets by the house which gathers them and something to which no one else has any right of access.

If the business man looks to economic theory for guidance, he may there find generalizations which give a sense of direction. The law of diminishing. returns, for instance, makes clear that, beyond a fixed point, increased expenditure secures less than a proportional increase in product. Cultivating a market is much like cultivating a field. Two " doses" of capital and labor may not bring twice the returns of a single adequate dose. There is a point at which the rate of return does not equal the rate of increase in expense. The larger the number of salesmen in a given territory, the larger as a rule the total number of orders. Yet the addition of 


\section{NATURE OF BUSINESS ACTIVITIES}

salesmen might be carried to a point where the average of orders per man might drop, the individual expense remaining constant, and returns from the field might fall below the level of profit. Another contribution of economic theory - that of the consumer's surplus - is discussed in the course of the book.

It remains true, however, that there is no body of scientific business principles on which we may rely. The study of mass phenomena on which broad generalizations must be based has not yet been organized. We have rules laid down by successful concerns as expressions of their practice or policies, the traditions and proverbs current in various industries and districts, and the recorded but largely inaccessible experience of numerous individuals and organizations. These methods and policies, of proved efficiency in certain businesses and under certain conditions, if brought together and classified according to their fundamental relations, could be compared with methods and policies which have proved effective in other establishments under similar or different conditions, and the underlying principles disclosed for the direction of rational business thought and the formation of sound business judgment.

But after all, it is by actually observing men at work, by studying them as they drive nails, shear steel plates apart, build up wood veneers, tend 


\section{MARKET DISTRIBUTION}

drill presses, crate finished products, calculate factory costs, fix prices, fill out order forms, write advertisements, pass merchandise across counters, negotiate loans, collect money, adjust complaints and perform the countless other operations of which the fabric of business is made up, that we can discover and verify the nature and relation of all these activities and develop a body of usable and dependable principles of business conduct for the management of a business. There are tens of thousands of these activities varying broadly in kind and in character. Is there an element common to all ? Is there any simple, unifying concept or principle, working with which a classification of these activities can gradually be disclosed that is obviously logical and practically usable?

\section{The Common Factor in all Operations}

Observe a workman in a factory directing the cut of a planer in a malleable steel casting, and we find that he is operating on a piece of raw material for the purpose of changing its form; a clerk in a store passing over the counter to the consumer a package of factory-cooked food and we find that his operation results in a change of place; a typist at his desk making out an invoice for a shipment of merchandise and we find that he is operating not to change the form of matter nor the place of commodities but to facilitate those changes. 


\section{NATURE OF BUSINESS ACTIVITIES}

The operations of business vary greatly in kind but always the essential element common to each is motion. ${ }^{1}$ If you examine any activity in any field or phase of business, the essential element invariably will be found to be the application of motion to material.

Starting with this simple concept it becomes evident that we have an easy and obvious basis for the classification of these activities. With the philosophical aspects of the concept itself I am not concerned. Sufficient that it gives us a simplifying, unifying principle from which to proceed, instead of a mere arrangement by kind or characteristic, of the material, men, operations and processes which we see in the various departments of a business enterprise. It is not the nature of the operation that is most to be considered. It may be an action that is common to all the departments into which the organization is divided, like the requisition of a dozen lead pencils or a box of paper clips. Or it may be a special and individual process that is not duplicated elsewhere, like the pouring of molten metal in the foundry or the making up of a payroll. Its character alone does not supply the key to a usable classification. It is not until we look to the common fundamental element and inquire: "What is the purpose of this motion?" that we find the key.

${ }^{1}$ See E. v. Böhm-Bawerk: Positive Theory of Capital, pp. 12-13. 


\section{MARKET DISTRIBUTION}

I do not wish to exaggerate the importance of this simple and apparently obvious idea, but for me it has opened a way to locate the activities of business and disclose the relations existing between them. It serves not alone as a key to a classification of these activities and a method of approach to the problems arising out of their relations but also as a thing of every-day use. For the final function of this classification is to locate those motions that are purposeless and further the conservation of energy by making their elimination possible.

This last does not always mean a reduction in the total number of motions: in our roundabout modern system of production, with its minute division of labor, we may make a greater number and variety of motions distributed over a longer period of time yet increase the eventual output or decrease the cost through the group effectiveness of all the motions. ${ }^{1}$ If you study an individual motion or operation in itself and in relation to the other activities surrounding it and no satisfactory answer can be found to the question, "What is its purpose?" you have strong grounds for assuming that it is a non-essential and useless motion. It may have the sanction of house tradition or trade custom, but its superfluous character remains and the wisdom of eliminating it becomes plain. This

${ }^{1}$ See E. v. Böhm-Bawerk: Positive Theory of Capital, pp. 17-20. 


\section{NATURE OF BUSINESS ACTIVITIES}

classification, therefore, becomes also a test of efficiency. Both from the individual and the social standpoint, any motion in business which has no purpose is a motion economically useless and wrong.

The Purpose of a Classification in Business

From the manager's view-point the purpose of this analysis is not alone to place the activities of business, to trace out their relations and study the problems that arise out of them, but to inquire into each motion and disclose what is its purpose. In the three typical operations mentioned - those of the factory workman, the retail clerk and the office typist - each application of motion was for a distinct purpose and each instance was representative of one of the three great divisions of business activities.

1. The activities of production, which change the form of materials.

2. The activities of distribution, which change the place and ownership of the commodities thus produced.

3. The facilitating activities which aid and supplement the operations of production and distribution. No adequate descriptive term suggests itself; facilitation is awkward, administration is inexact because it suggests all the relations of the management to a business 


\section{MARKET DISTRIBUTION}

rather than a separate group of functions towards which the manager should maintain the same sort of relations as with those of production and distribution. ${ }^{1}$

Whatever the nature or kind of any business activity, its final effect is one of the three just indicated.

Pursue the inquiry further, studying all the motions that contribute to production and inquiring the purpose of each, and it is apparent at once that they fall into one or other of two groups, according as they have to do with plant or opera-

1 Business men and economists, though dealing with the same forces and the same phenomena do not always agree on terminologyl The economist speaks of the agencies of production as land (or natura. agents), labor, capital and organizing ability; and he includes in production the activities which the business man groups separately under the heads of distribution and various facilitating functions. To the business man the term production covers all the activities which are concerned directly with the manufacture of articles. He uses concrete terms: plant and equipment instead of capital, materials instead of land or the products drawn directly from the land. He uses the economist's term in describing the active agency as labor, but speaks of organization rather than of organizing ability. It is to be remembered, of course, that their view-points are diffcrent: the economist having the social view-point, the business man that of the individual engaged in conducting an enterprise for profit. In the following pages the language of the business man is used, though it has been necessary occasionally to find new phrases to characterize the re-grouping of activities which has been attempted. Any awkwardness in terminology which has resulted will not, I trust, prejudice the reader's consideration of the ideas themselves. 


\section{NATURE OF BUSINESS ACTIVITIES}

tion activities. Within each of these groups the line of obvious division continues: every individual operation finds its place naturally and without question. The plant activities separate into those concerned with $(a)$ location, $(b)$ construction, $(c)$ equipment - the providing of a ready-to-run factory. The operating activities split up into those that have to do with $(a)$ materials, $(b)$ the men who make the motions which change the form, and (c) organization - such adjustment and control of materials and motions as will get the most effective result.

\section{The Bastc Principle of Interdependence}

In their broad aspects the problems of location, construction and equipment are parallel and interdependent. No one of them can be solved and the efficiency of the plant insured unless allowances are made for the inflexible factors of the others. The operating activities, in their turn, are so closely knit together and so influence and are influenced by the plant activities that no single factor can be weighed and determined by itself alone, but must be considered also in its relations with all the remaining activities of both groups. This mutual interdependence extends as well to all the activities of production, distribution and administration.

Every man of broad experience will recognize this interdependence, I think, as a basic principle 


\section{MARKET DISTRIBUTION}

in business. Likewise its corollary, that a balance must be maintained in these relations. The ratio of cost, quality and service observed in the actual manufacture of a product, for example, must be the same as that put forward by the sales force. Otherwise customer dissatisfaction will follow, internal friction will develop, and efficiency, good will and profits all will suffer. Or, again, the attitude of a credit manager who does not consider the effect of stringent credit policies on sales may hamper the efforts of a capable and enthusiastic selling force.

An introduction to an essay on market problems - for that is the character of this first chapteris not the place, however, to trace out factory relations and dependences. I have indicated them here, because in dealing with the tangible materials and motions of production, the application of this method of approach and the development of this classification are more clearly illustrated on account of the definite and measurable character of the things classified. On the other hand, the activities of distribution, dealing with intangible quantities and adding no objective utility to the goods, though they present a more complex problem for analysis, yield to a similar approach a parallel classification.

When we examine the activities of distribution, the first broad classification according to purpose 


\section{NATURE OF BUSINESS ACTIVITIES}

results in two sub-groups - the activities of demand creation and those of physical supply.

The activities of demand creation focus on the consumer. Their purpose is to communicate to his mind such ideas about the product as will arouse desire for it and cultivate willingness to pay the price and make the effort required to secure it.

This aroused demand would have no commercial or economic value unless provision were made for satisfying it by actual transfer of the goods through one or more of the available agencies. The relations between the activities of demand creation and physical supply illustrate again the persistence of the two principles of interdependence and of balance throughout the whole structure of business. Failure to coördinate any one activity with its group-fellows and also with those of the other groups, or undue emphasis on any one of these activities, is bound to destroy the equilibrium of forces which means efficient distribution.

You cannot solve your first problem: How can a demand for this product be created of sufficient volume to make its production profitable? unless you consider at the same time the accompanying problem: Through what channels can this article be conveyed from the factory warehouse, where it is of least value, into the hands of those consumers who will pay the most profitable, though not necessarily the highest, unit price for it? 


\section{MARKET DISTRIBUTION}

The parallel with production takes shape when the activities of demand creation split up into those which are concerned with plant and with operation. It continues when the plant activities group themselves, still according to purpose, under location, construction and equipment: while the operating activities divide according as they are occupied with either materials (ideas about the goods), the agencies by which these ideas are transmitted to consumers (corresponding to labor in production), and organization.

\section{Parallels between Production and Distribution}

In both production and distribution, plant policies practically crystallize after they are established, while the operating activities present fresh problems to the management every day. In demand creation these claims on his attention are multiplied and the difficulty of analysis and decision are intensified because of the general lack of standards and because all the factors engaged are quantities not easily measurable, unstable human relations or the unexplored complexities of market psychology.

The only mental readjustment this classification requires of any business man is assent to the concept that ideas about the goods are truly materials of demand creation. The terminology is new and the assumption broad, but I think it holds in every- 


\section{NATURE OF BUSINESS ACTIVITIES}

day business. Certainly it simplifies any approach to the problems of distribution: since ideas about the goods are the selling points from which salesmen, middlemen, and advertising men develop arguments and demonstrations to arouse in the consumer's mind interest in a product and a desire to possess and enjoy it.

Despite the fact that demand creation is largely a problem in applied psychology, there is a close analogy between the materials of demand creation and factory materials - to both of which motion must be applied in order to render them effective. Ideas about the goods can be handled as definite things, almost as tangible as raw stock. The results they produce can be measured with a fair degree of accuracy - particularly in advertising, where the personality of a salesman does not enter to confuse the issue. This means that the sales value of each idea can be tested, that different arrangements of the same ideas can be compared and that the relative efficiency of the agencies employed for their transmission can be determined. The written and printed symbols, too, which represent a given idea or series of associated ideas can be indexed and filed precisely as the materials used in manufacturing are inventoried and stored until the time comes when they are needed for use.

Here enters the value of the concept that ideas about the goods may be treated as the materials of 


\section{MARKET DISTRIBUTION}

demand creation. Considered as materials, they can be submitted to analytical processes like those which the materials of production undergo in the factory laboratory in the development of standards by which to measure their quality and to guide manufacturing operations. A certain amount of attention is given in a later chapter to this testing and refinement of selling points - an attention warranted I think by the significance of the idea and its relative neglect in distribution today.

Standards are conceded to be indispensable in the factory merely to direct and check the buying and processing of materials. Analogous standards are even more effective in demand creation for the reason that every selling point which proves itself under test becomes so much inexhaustible material which can be used again and again in diverse ways alone or in combination with other ideas about the goods, by the different agencies available for its transmission.

For all these ordered activities - the gathering, classifying, testing and standardizing of the materials of demand creation - the rule-of-thumb tribe has its equivalent in the "first sell yourself" which is an axiom in the practice of salesmanship.

It may be possible, in time, greatly to extend and simplify this analysis of materials. As yet the professional psychologist has addressed himself to 


\section{NATURE OF BUSINESS ACTIVITIES}

few of the problems which engage the attention of business men. ${ }^{1}$ And even the conclusions already arrived at are rarely of practical value - chiefly because the psychologist, in framing his tests or phrasing his questions, is not always cognizant of the things the business man wants to know.

He has been known to submit a series of advertisements to a group of thirty, forty, fifty students (themselves far removed in character, tastes and purchasing power from the average consumer) and to ask them to indicate which is the most effective of the lot. Given like opportunity, the business man would select really representative subjects and would put a specific purpose behind each query: "Which advertisement would get your attention first? Which one would hold your interest? Which one would stir curiosity or make you want the product enough to ask for it by letter or at the nearest store?" And so on, breaking the single question up into perhaps a dozen specific inquiries which would give definite information as to the size, the shape, the quantity and character of ideas, the kind of illustration and the style of argument which would secure and hold the reader's attention and bring him to the action desired of him whether this be the filling out of a coupon or the inclosure of a signed order and check.

${ }^{1}$ See Boris Sidis, The Foundations of Normal and Abnormal Psychology: Preface, pp. 3 and 4. 


\section{MARKET DISTRIBUTION}

The possibility of formulating standards for things so intangible may be challenged by the average producer, no matter how scientifically he has standardized his factory materials. For here as elsewhere in the field of distribution too many business men have adhered to the rule of thumb.

\section{The Rule of Thumb in Business}

They guess at the most effective sales ideas which analysis of their product discloses, guess at the most forceful forms of expressing these, and guess at the most efficient agencies and mediums for transmitting them to prospective purchasers. They spend in the aggregate millions of dollars every year on selling campaigns based on a series of approximations or opinions arrived at in this loose fashion.

The need of a searching study of all the activities of distribution by government and private agencies, working together on a coördinated plan, is emphasized by the appalling waste of money, effort and merchandise due to this general lack of standardization in the materials of demand creation as well as all the other factors bearing on the efficiency of our marketing system. I believe that the federal government should undertake a systematic inquiry into the activities of business, in coöperation with the private agencies, trade associations and universities already engaged in the work, with 


\section{NATURE OF BUSINESS AC'TIVITIES}

the idea of collecting, classifying and standardizing all available information, and should establish some permanent agency for disseminating this knowledge among the business men of the country. ${ }^{1}$

But to return to our classification. After he has gathered and tested his materials of demand creation, the business man's next problem is to determine how he can transmit these ideas about his goods to the minds of possible consumers so directly and accurately that they will adopt his view of the product and forthwith become purchasers. For this work of communication, he finds that three important agencies have been developed - the middleman, the direct sales force, and advertising, both direct and general. He must decide which of the three will best perform the work of demand creation without interfering with other necessary activities of production and distribution - those of physical supply for instance - or whether two or more can be combined advantageously or used independently in different geographic or social or economic sections of the selling field.

This is a vital problem of the producer, and these are some of the questions he must ask: Shall I sell direct or through the trade? And if my goods move to the consumer through the recognized channels, shall I depend on the successive middle-

1 I have advocated this idea in the editorial pages of System, at various times for several years. 


\section{MARKET DISTRIBUTION}

men to do all or any part of the work of demand creation? Or can I take on the entire burden of advertising and selling without prohibitive increase of expense, and leave to the wholesaler and retailer only the function of supply - of stocking my products and handing them out to the consumer when they are called for?

Current merchandising practice embraces the entire range of possible procedure, from absolute dependence on the middleman for all the work of demand creation, through every degree of coöperation in selling, to complete assumption by the manufacturer of the task of developing and perpetuating a market for his goods. A great number of branded and nationally advertised food products illustrate this last stage. Trade-marked and advertised lines of clothing, tools, household appliances and the like occupy the intermediate positions marked by coöperative selling. And thousands of commodities prepared by concerns which limit their activities to production alone, represent the first extreme of marketing dependence.

The evolution of what might be called the orthodox system of distribution is considered at some length in the following pages. It is needless, therefore, to anticipate the analysis or the conclusions which the reader will encounter there or to enlarge upon what some think an apparent tendency to eliminate the middleman not only in 


\section{NATURE OF BUSINESS ACTIVITIES}

demand creation but in the physical supply of commodities.

\section{Shortening the Cycle of Distribution}

This drift towards a shortened cycle of distribution by all the agencies involved is one of the most interesting developments in modern business. Starting with the manufacturer's assumption of various functions performed by the middleman, it has brought about a counter movement with a like purpose among both wholesalers and retailers. Many manufacturers of shoes, clothing, and silverware (to mention only the most typical lines) virtually ignore the wholesaler, selling and shipping direct to the retailer. Many others have cut out all middlemen and deal with the consumer in person, either by the mail-order route, through exclusive stores or through special salesmen.

To compensate for this loss in volume, the wholesaler has developed his own "house brands" and reduced the chain by one member, practically turning manufacturer himself. Even here there is divergence in method. Of two great merchandising houses which are my neighbors in Chicago, one has adopted the policy of controlling important sources of supply through actual ownership, while the other prefers to identify many small producers with its organization, furnishing them with working capital, patterns or style suggestions and a 


\section{MARKET DISTRIBUTION}

market for their total output, thus allowing them to concentrate on production problems alone. The large retailer, too, by developing exclusive sources for his principal lines has short-cut distribution no less effectually than has the manufacturer who sells direct to the consumer.

Analyzing the results of these antagonistic movements to simplify the production-distribution equation, the manufacturer seeking a market for his product must ask himself whether the apparent elimination of the middleman is as real and as conclusive as it seems at first sight. He must consider the probability that his elimination of the middleman in his particular business will not eliminate him from the general marketing scheme in his trade. And finally he must determine whether in his individual case the wisest course is to divide the functions of distribution with coöperating middlemen or to divide the market with as many extra competitors already in touch with the trade.

For an endless variety of non-staple articles "specialties" in the language of the market place - it remains true that anything like maximum sales is impossible unless consumer advertising or a direct sales force is employed in demand creation.

If the product be simply a bettered staple, retaining its familiar characteristics and depending on refinement of design or finish to recommend it, no particular urging is necessary to stimulate the 


\section{NATURE OF BUSINESS ACTIVITIES}

middleman's interest and secure his order. Any advance in price or decrease in quantity operates against this easy acceptance, of course, even when specialization gives the product an added or unique utility.

Where the character, quality, or use of the article, however, is not evident at a glance but requires demonstration or the development of ideas unfamiliar to the trade and the consumer, the work of transmitting these selling points through two or more middlemen is attended by difficulties. The chief difficulty arises because the differentiated product requires individual handling at every stage of demand creation, while conditions are against its chances of this special attention. When it is also competing for the middleman's interest with private brands or with articles of lesser quality which are more easily sold or allow the middleman a greater unit profit without jeopardizing sales, its chances of demand creation at first hand are even further diminished.

\section{The Practical Problem in Distribution}

Whether advertising by the producer and the direct sales force usurped the middleman's function of demand creation or were evolved to perform a neglected task is of no immediate moment. All three agencies exist and are likely to continue active in distribution as long as individualism holds 


\section{MARKET DISTRIBUTION}

its place in affairs. To the business man - in a very real measure to society as well - the important thing is to determine when and how they can be combined or can be used independently to create maximum demand for a product with a minimum outlay of effort and expense.

This consideration of the "when" and "how" of utilization brings forward the third and final group of operating activities under demand creation - those having to do with analysis of the market from the view-point of economic and social strata as well as of geographical areas, the fixing of prices and the choice or combination of agencies. The guiding policies of this group and their relations with one another and with the other activities of distribution will be found outlined in the subsequent chapters of this book.

Not to weary the reader with a fresh application of a familiar analysis, it will be enough to say here that the second grand division of the activities of distribution - that concerned with the physical supply of commodities - breaks up into groups analogous to those already indicated under demand creation. Classified according to purpose, the first grouping disclosed is exactly the same: plant activities and operating activities.

The parallel continues through plant activities; these have to do with location, construction or equipment. Under operating activities the com- 


\section{NATURE OF BUSINESS ACTIVITIES}

modities to be distributed correspond to materials in the other groups, while the agencies are either the fractional middlemen of the orthodox system, a direct supply organization, like branch houses or an exclusive delivery force, as in city and suburban territories, or functional middlemen like the express, warehousing and transportation companies which offer direct access to the consumer. The establishment of a domestic parcel post, equipped to handle twenty-pound packages and to make collections on delivery, has provided another cheap, popular and universal vehicle for delivering merchandise to the final user. Organization, in its turn, is concerned with analysis of the market or territory to be served and selection or combination of the agencies which will supply the aroused demand at minimum expense and with the least possible leakage of this demand.

\section{The Division of Labor in Management}

So much for the recognized activities of production and distribution. There remains a third basic division already suggested as the facilitating activities of business - financing, credits and collections, purchasing, employment, accounting and auditing, records and statistics, office management. As the division of labor was carried further and further in the activities of production and of distribution, the control of these activities became 


\section{MARKET DISTRIBUTION}

both complex and difficult. The pieces on the chess board of business were multiplied and the final result came to depend more and more on the way in which each piece was manipulated to forward the general plan. The necessity of coordinating and handling the countless resulting details compelled the management to deal with paper representations of the materials, motions and relations involved instead of directly with the things themselves.

The possibility of thus keeping in touch with the significant activities of a business had the further effect of greatly enlarging the size of organizations and the scale of operations. ${ }^{1}$ And finally, the extent and complex character of business as well as the distance of the controlling executives from the things controlled, put such a premium on efficiency in all these facilitating activities, that the principle of the division of labor was extended. The classification and organization of the functions of administration followed as a matter of course.

The introduction of machinery for compiling and assorting statistics, for writing reports and tabulating information, for checking mental calculations, is indicative of the great increase in the volume of administrative activities and the number of motions into which these operations have been broken up. By reason of their number, scope and

${ }^{1}$ See Alfred Marshall: Principles of Economics, IV, xI, 278-289. 


\section{NATURE OF BUSINESS ACTIVITIES}

importance, they have forced recognition as a separate group of activities apart from but coördinate with those of production and distribution. The need, therefore, is imperative for an organized method of bringing them all together, of establishing their relations and of holding them at such distance from the executive that no one of them shall exercise undue influence on his decisions in short a method of keeping them in balance with all the other activities of the business.

\section{How a Claassification Places Activities}

The general tardiness in discovering a common purpose in their functions is probably due to belated analysis. In the small or medium-sized business the usual practice is to make the production and sales organizations responsible for such administrative activities as are apparently related, or to retain them under the immediate eye of the executive. Only the larger concerns, facing the urgent problem of keeping their operations effective and under control, have set them apart as a group of auxiliary functions directly contributing to but impossible to classify as activities of either production or distribution.

Confronted with this multiplicity of motions and operations, the manager, as well as the student of business, finds that some scheme of classification is necessary to make their relations clear. When we 


\section{MARKET DISTRIBUTION}

inquire their purpose, therefore, their common character as the facilitating activities of business comes out immediately. Pursuing the analysis along the lines already made familiar, we discover that they break up first into two groups concerned with plant and operating functions. As before, the first group sub-divides, according as the functions relate to location, construction or equipment. When we take up the operating activities, we find that they also split up in the accustomed way and range themselves under materials, labor and organization. ${ }^{1}$ But there is an important difference; the materials of administration or facilitation that to which motion is applied - are the paper representations of the functions which are performed. These paper representations are either causal - purchase or employment requisitions, or shipping requisitions; or resultant - outgoing in-

${ }^{1}$ How this classification squares itself with current business practice may be easily tested. Purchase requisitions refer to plant and equipment or to materials and supplies, while employment requisitions have to do with labor. They originate in either the manufacturing, the distributing or the facilitating activities of the business. The first two groups of functions center in the purchasing agent, and labor brings us back to the employment bureau or official of the average concern. Besides the factory or finished stock departments, the shipping requisitions directly involve the credit man, who must pass on the order before it is honored by either. On the resultant side, the outgoing invoices are the affair of the collections department; the vouchers represent the responsibilities of the financial end of the business, and the house records are the concern of the accounting, auditing and statistical departments. 


\section{NATURE OF BUSINESS ACTIVITIES}

voices, vouchers, and general and department records.

Of the two remaining groups of operating activities, labor presents problems much like those encountered in determining the labor policies of production. If anything, the selection, training, paying, and handling of an office force is the more complex task. Finally, the problems of organization parallel those brought forward in the organization of the activities of distribution.

Within the various departments, functions are generally well understood; nevertheless it remains for the manager to determine how his departments shall divide or concentrate these functions, and to establish policies which will insure all-round coöperation. The human factor is vitally important, of course. The character and scale of the business, too, help to define the scope and functions of each department. As the organization increases in size, certain functions take on added importance both because of the volume involved and because there is less of personal contact between department heads. Hence it is that many concerns have transferred the handling of these from production or distribution to an administration group of activities.

Is there a practical reason for recognizing a new classification for these functions and for bringing them together on their common plane of facilitat- 


\section{MARKET DISTRIBUTION}

ing purpose? Does it serve any useful end ? To my mind, it does. The head of every business, in determining and maintaining consistent policies towards all its activities, finds himself controlled as we have already seen, by the principle of interdependence and the principle of balance. The typical business exists, however, because the man behind it is a specialist. He has capitalized his buyer's instinct for values, his salesman's tact and enthusiasm, or his patience and resources as shop organizer. He has built on this special ability, and unless he has some systematic method of analysis and some broad scheme of classification to correct his leanings, he is apt to depend too much on his specialty and neglect other necessary functions.

\section{The Strategic Position of the Manager}

The strategic position for the manager, therefore, is one free from the routine of any department yet in touch with the significant details of all. From no other view-point can he secure a clear vision of his business, protect himself from department bias and overcome a tendency to lay too much stress on the activities which are most familiar or most interesting to him.

I do not mean that the head of a business must withdraw from all contact with details in order to keep his perspective. In innumerable small businesses, the owner-manager is of necessity the sales 


\section{NATURE OF BUSINESS ACTIVITIES}

manager or factory superintendent, the advertising manager or the purchasing agent - to say nothing of his handling of finance and perhaps of credits and collections. It is to just such a man indeed that the classification of business activities here proposed should be of greatest value, since it emphasizes as of equal importance with production and distribution those facilitating activities which are frequently slighted because the consequences of neglect are slower to appear.

In the large business, it is true, the management deals with details, but they are symptomatic details. The popular conception of the head of a big enterprise is of a man engaged in transactions involving millions of dollars; yet in a business of great size it may be a mere matter of routine to put a note for a hundred thousand dollars in the bank, while a complaint involving forty cents may be a significant detail, which the head himself must handle because it involves delicate relations between departments or still more delicate relations between the business and its public. The big business man, therefore, is constantly handling details - not routine trifles but symptomatic details.

Acceptance and use of this classification does not require the formal partition of an organization into production, distribution and administration divisions - though this plan of organization is now successfully employed by leading American con- 


\section{MARKET DISTRIBUTION}

cerns. The purchasing agent in any given case may remain a factory official or the experimental department may continue to work under the sales manager. The important thing is that the manager himself should recognize buying and providing for the future needs of customers as activities which interest not the factory and the sales department alone but the entire organization. Viewed thus, their oversight and direction are as essentially the manager's concern as supervision of making and selling operations.

By placing them as facilitating activities related to the whole business, on a par with production and distribution, the scheme of classification gives the manager the correct focus and a rational approach to the problems arising from them. His own traditional function of finance, for instance, may bulk so large in any survey he takes of the business that it entirely obscures the damage a narrow financial outlook does to sales and production. The proper placing of finance as a facilitating function, of no greater importance perhaps than many others, might establish the missing balance which is hampering the whole enterprise.

The first service of any good classification, indeed, is to allow the man using it to back away from the things with which he is immediately occupied and to see all the activities involved in their true relations and proportions. This strategic position, 


\section{NATURE OF BUSINESS ACTIVITIES}

aloof from details, or at least recognizing them as details, leaves him free to view the broader problems which changing conditions and increasing social control of private enterprises are proposing for his solution.

\section{Society Challenging its Return from Business}

Unless he is blind or very obstinate, the business man must realize that he is no longer autocrat over his undertaking, able to base his policies on whim or personal prejudice or an entirely selfish conception of business. Society is asking of its college men what return in community service they are making for the exceptional training advantages accorded them. And public opinion is beginning to put the same query to business men in sharper and more specific fashion.

"Here," society says, "you have been given opportunities and advantages in your businesses such as no body of men at any other stage of the world's progress ever enjoyed. You have raw materials, fuel, buildings that are cheap, abundant and of excellent quality. You have machinery of surpassing ingenuity and capacity, able to perform almost any task you set for it at a cost amazingly slight. You have labor of exceptional intelligence to direct and supplement the functions of these machines. You have a comprehensive transportation system which makes a great continent - the 


\section{MARKET DISTRIBUTION}

whole world indeed - a market for your product and a source for your supplies of labor, materials and equipment. Almost every necessary element and favorable condition you could ask are provided for you. You have only to supply the organizing ability which will pick out the right product to make or sell and choose the right materials, the right equipment, the right location, the right method of marketing. Over against your organizing ability and capital, I set these contributions of mine. What besides the market minimum of value and service at the price are you going to supply as $m y$ profit on $m y$ investment of community machinery and opportunity?"

Without formulating its approach to the problem, society has been applying more and more inclusively the basic test of purpose to the activities of business men. It has come to feel that so large a margin has been allowed that it permits them to practice many of the mere arts of commerce. It has sensed the existence of useless motions, observed the needless duplication of essential functions, and in some cases - the establishment of a parcel post to carry package freight in competition with the express companies, for example, - it has sought a drastic short-cut to a fairer balance between service and cost.

In other instances it has adopted milder measures of regulation and adjustment, as in the work 


\section{NATURE OF BUSINESS ACTIVITIES}

of the Interstate Commerce Commission, the projected functions of the Federal Trade Commission, and the activities of state and local boards for the supervision of trades and industries.

\section{The External Problems of Business}

From this attitude of society, crystallizing after long agitation into definite policies of regulation, arise what may be termed the external problems of business. If I were to chart the broad relations of any individual business, I would represent its internal and external activities as two circles impinging upon one another, with the management on the alert at the point of contact. The internal problems would arise out of the relations of the activities of production and distribution and what we have been calling administration. The external problems would have to do first with the special public the business is concerned with - its customers and prospects, its competitors, and the general body of labor from which it draws its workers - sales, executive, clerical, or factory. And outside this circle, I would trace another much larger to indicate the relations of the business with the general public.

In dealing with both these social groups, however, the manager is not so much concerned with the immediate activities observed, as with the actuating motives of which the actions are the 


\section{MARKET DISTRIBUTION}

expression. When he begins studying the public and its relations with his own undertaking, he finds that he must take account first of the motives likely to influence the various social groups or strata to action favorable or unfavorable to his purposes. The comfort his employees take from their pleasant, well-lighted and well-ventilated work rooms, for instance, is likely to reflect itself in a community esteem which will react on local sales and on the attitude of that section of the public from which he draws his workers.

In determining the policies which shall govern his relations with the general public, the business man will recognize three modifying influences - or three phases of the same powerful influence - to which he must accommodate his activities. Of these, the hardest to understand yet the real force to reckon with is public opinion - the reaction of contemporary thought or emotion or ethical sense upon the activities of business and the conditions under which they are carried on.

The law is the second of these influences, but law is simply the crystallization of public opinion into a definite enactment; while the government, the third influence, is only an administrative agency for putting this formulated public opinion into effect. The wise man is the man who keeps abreast of public opinion, who detects the changing view-point of the country or the community 


\section{NATURE OF BUSINESS ACTIVITIES}

and so modifies his individual business practice that he escapes entanglement later with the operations of the law or the machinery of the government. The average business man, submerged in the activities of his undertaking, has at times either not caught society's drift or has not realized its vital bearing on his business. Not until the law formulating this public opinion was enacted or about to be enacted has he awakened to its purport, and then discovered that the people, through various civic organizations, had been studying the underlying question much longer than he had suspected.

Public opinion is the fundamental force, yet even now business men are more intent apparently upon the interpretation of the law and the attitude of the government than upon developments in the public mind.

Watching all this legislative, judicial and administrative machinery in motion, the owner or manager of a business may too readily conclude that his important external problems are chiefly concerned with it, not with smoking-car debates, the gossip of a switch shanty or the discussions of a woman's club. But it is this talk and the convictions that emerge from it that are the things he must consider. The passage of the Interstate Commerce Act in 1887, for instance, was the first break in a long continued policy of federal en- 


\section{MARKET DISTRIBUTION}

couragement of private enterprise, particularly evident in the subsidies and land grants to railroads and the protective tariff for the fostering of industries. The Sherman Anti-Trust Law followed in 1890, but a dozen years were to elapse before court decisions defining the jurisdiction of the Interstate Commerce Commission and the inclusive scope of the Sherman law emphasized the principle of control underlying both enactments.

\section{The Dominant Influence of Public Opinion}

No better illustration could be cited of the power of public opinion to modify the established law as interpreted by the courts and administered by the government. The Commerce act as adopted expressed the current feeling that discriminations in railroad rates for or against individual shippers or communities constituted a menace to the business of the country. The Sherman law was quite as definite in its attack on contracts and combinations in restraint of trade. But neither effected any radical change in the practices they were aimed at until the courts and the national government began to feel the pressure of an aroused public sentiment a full decade later. Had the railroads taken cognizance of this public opinion and reshaped their rate and traffic policies in accord with it, they might have been spared some of their troubles in the last seven lean years. 


\section{NATURE OF BUSINESS ACTIVITIES}

This pressure has continued and grown stronger. Witness among other effects, the decisions of the United States Supreme Court dissolving the Northern Securities Company and the oil and tobacco combinations, cancelling the exclusive anthracitic coal contracts, affirming the right of the Commerce Commission to fix general or zone rates on its own initiative, and declaring the constitutionality of the long and short haul clause of the Commerce act.

On the administrative side, again, there is the defensive suit pending against the International Harvester Company, which hinges on the ability of that concern to throttle competition rather than on any actual efforts to that end. And finally the legislative program of the last Congress included the Clayton law defining unfair trading practices, and the act establishing the Federal Trade Commission - the latter body standing towards business in general in much the same relations as those which the Interstate Commerce Commission maintains towards the railroads and the shippers of the country.

This increasing concern of the federal and the state governments with business practices opens up a new set of external problems to the average manager. In the past, as a rule, he has left the threshing out of proposed restrictive legislation or administrative orders to the larger commercial and 


\section{MARKET DISTRIBUTION}

industrial units, on the theory that their interests in the matter were so great that they could be trusted to represent his interests also, or for the more specific reason that usually he did not realize the importance of the question until it was brought to his attention by the action of these larger concerns.

\section{The Atritude of the State towards Business}

In the future, however, the attitudes of the national and state governments towards business are bound to have an increasing influence on the conduct of every factory and store. No longer can the head of a small business leave the adjustment of his relations with the law, the government and public opinion to the grace of his big neighbors or competitors or the zeal of the men who run his trade association. He must coöperate with his trade rivals and associates in conveying to the public in general and to the men who make and execute the laws an understanding of the activities, the relations and the necessities of business. Otherwise ill-conceived or doctrinaire legislation will hamper the operations of trade and industry to such a degree that the burden of added expense, under the law of competitive business, will have to be passed along to the consumer.

Regulation must be intelligent; it must be at the hands of men who know the technique of 


\section{NATURE OF BUSINESS ACTIVITIES}

business, who can distinguish between essential and non-essential activities, and can further the first while they are eliminating the latter. In selfdefense, therefore, as well as for the sake of progress, every business man must begin to consider the shaping of legislation and the choice of administrative officials as serious external problems of his business. Public opinion needs to be informed about business, its problems, and its complexities. It is not, however, for the sole purpose of educating the public and its law-makers that the business man should interest himself in public affairs and opinion. The business man needs more than ever today to gauge the depth and directions of social currents.

Summed up, then, the business man has two distinct groups of problems to consider. In approaching and solving them he must keep always in mind the universal application of the principles of balance and of interdependence. He must remember that no question can be dealt with in the light of departmental requirements alone, or even as one affecting only production or distribution or administration policies. Instead, it must be handled as a matter involving many, perhaps all, of the other activities of his business. But more is necessary; he must not only perceive these contacts and establish right relations between activities within his organization and within the circle of 


\section{MARKET DISTRIBUTION}

his special public, but he must accommodate his policies and his practice with the convictions, and at times the sentiments of the general public as expressed by the Law, the Government and Public Opinion. In a word, the external problems of business are become internal problems in the sense that no intra-organization policy can safely be determined without taking into account the attitude of society towards the activities involved. 


\section{CHAP'TER II}

\section{PROBLEMS OF THE DISTRIBUTOR}

The business man is concerned with the production and distribution of goods. Factory production he finds relatively well organized. The era of the rule of thumb is passing, and the progressive business man can call upon the production expert, technically trained, to assist him in solving his problems of production. But the marketing of the product has received little studious attention. As yet there hardly has been an attempt even to bring together, describe, and correlate the facts concerning commercial distribution. Selling is on a purely experimental basis.

The progress that has been made in organizing production is the result of systematic study. For centuries attention has been concentrated on the problems of production. Methods of study that have proved fruitful in other fields have been applied to the problems of manufacture and a body of organized knowledge is being built up.

Now the problems of market distribution are no less worthy of systematic study than are the problems of factory production. It is as essential that the finished goods be moved from the stock room 


\section{MARKET DISTRIBUTION}

of the producer to the hands of the consumer, as it is that operations be performed upon the raw material to produce the finished goods. And the problems of marketing are even more complicated than the problems of manufacturing, because the human factor is of more direct importance.

Why has not systematic study been given to the problems of distribution? The explanation is found in a glance back in our economic history. Chief among the causes for the industrial changes leading to the establishment of the factory system in England in the eighteenth century was the constant widening of the market. It was a rapidly increasing pressure on the producer for greater quantities of staple articles for mass consumption that gave incentive to the revolution in the method of production. For a century thereafter the necessity of supplying a continually widening market, as means of transportation steadily improved and the population increased with unprecedented rapidity, made production the dominant problem. Economic conditions have put the emphasis on production.

Where the felt need is greatest, there will the organizing ability of the human race concentrate itself. The problems of production were sensed as the most pressing that faced society. He who improved methods of manufacture to increase output or reduce cost reaped a large reward. Hence the ablest minds were drawn toward the solution 


\section{THE DISTRIBUTOR}

of those problems. The business manager gave his best thought to the difficult task of producing more goods at lower cost. The constantly widening market made selling a comparatively simple problem.

As a result we have built up a relatively efficient organization of production. While much remains to be done, the resources of modern science are being utilized to improve and organize our agencies of production. The development of producing capacity has been tremendous. New processes have been and are being introduced. New forces have been called into play. Methods are constantly being scrutinized to effect a more economical and efficient organization of production. The recent introduction in many industries of so-called "scientific management" is only a partial crystallization of long years of progress.

While we are only upon the threshold of the possibilities of efficiency in production, the progress thus far made has outstripped the existing system of distribution. If our producing possibilities are to be fully utilized, the problems of distribution must be solved. A market must be found for the goods potentially made available. This means, in the main, a more intensive cultivation of existing markets. The unformulated wants of the individual must be ascertained and the possibility of gratifying them brought to his attention. 


\section{MARKET DISTRIBUTION}

There are some, to be sure, who deplore the increasing complexity of human wants. This is a problem for the philosopher, not for the business man. Our whole civilization has been characterized by an increasing standard of living due to the demand on the part of the individual for more goods and more highly differentiated goods. The business man finds his practical task in searching out human wants and providing the means of gratification.

Not only does the chaotic condition of distribution act as a check upon further development of production, but it also involves a tremendous social waste. The consumer pays for "lost motions" in distribution as surely as he does for "lost motions" in production. Society can no more afford an ill-adjusted system of distribution than it can inefficient and wasteful methods of production. The social cost is no less real.

The most pressing problem of the business man today, therefore, is systematically to study distribution, as production is being studied. In this great task he must enlist the trained minds of the economist and the psychologist. He must apply to his problems the methods of investigation that have proven of use in the more highly developed fields of knowledge. He must introduce the laboratory point of view. To that end, an attempt here is made to outline some of the problems of 


\section{THE DISTRIBUTOR}

commercial distribution from the point of view of the business man, to analyze them, and to point out some methods of systematic study of these problems.

\section{Situation in the United States}

The problem presented by the United States as a consuming market is a complex one. Here are a hundred million people distributed over an area of more than three million square miles (excluding Alaska). Some are gathered in the large cities, where millions jostle elbows. Some are scattered over great areas with considerable distances between them and their neighbors. Some daily pass hundreds of retail stores; some must ride miles to reach the nearest store. Wide extremes in purchasing power exist. Millions have a purchasing power scarcely sufficient to obtain for themselves the barest necessities of life. A few can satisfy the most extravagant whims of the human imagination. Between these extremes lie all degrees of purchasing power, the number in each class becoming greater as you descend in the scale of purchasing power.

Their wants are as varied as their purchasing, power. Environment, education, social custom, individual habits, and all the variations in body and mind tend to render human wants diverse. In each individual there are certain conscious needs being constantly gratified by the purchase of goods' 


\section{MARKET DISTRIBUTION}

produced for such gratification. Then there are the conscious needs which go ungratified because of the limitations upon purchasing power and the existence of other needs of greater felt importance. And then there are the unformulated, subconscious needs which fail of expression because the individual is ignorant of the existence of goods which would gratify them. Twenty years ago, to illustrate this last class, there existed in the farmer, far from a barber shop and clumsy in touch, an unformulated need for a safety razor. Today, the distributor forces upon his attention the existence of such a device and the unformulated need finds expression in effective demand.

The accepted system of distribution was built up on the satisfying of staple needs. The pressure of the market discussed above made it unnecessary for the business man to search out unformulated human needs. Only in recent years, when the development of production, potentially outstripping the available market, has shifted the emphasis to distribution, has the business man become a pioneer on the frontier of human wants. Today the more progressive business man is searching out the unconscious needs of the consumer, is producing the goods to gratify them, is bringing to the attention of the consumer the existence of such goods, and in response to an expressed demand, is transporting the goods to the consumer. The task 


\section{THE DISTRIBUTOR}

is one of adjustment. The materials and forces of nature must be bent to human use.

This sort of activity has not only built up new consuming power in the market, and contributed to the progress of civilization, but has given rise to new price policies that have undermined the old organization of distribution in staple lines. Hence it is important in outlining the present day problem of distribution to give special attention to the more progressive distributor, rather than to the typical distributor.

It is not alone to revealing and gratifying unformulated wants by the creation of new goods that the more advanced business man turns. He finds like opportunity in the difference between the market price that has come to be established for a known commodity and the varying subjective valuations placed upon such a commodity by consumers of differing purchasing power and of differing social position and individual habits.

The economists tell us of the " consumer's surplus." Briefly, this is the difference between the market value for a commodity and the subjective value of the commodity to the individual consumer. Each individual sets up for himself a ratio of exchange between commodities which finds expression in the price he would be willing to pay for a given commodity rather than go without it. These subjective valuations constitute the demand 


\section{MARKET DISTRIBUTION}

side of the market. The interplay of supply and demand gives rise in a competitive market to a price at which the consumer can obtain the article.

If this market price is above the level that is fixed by the subjective ratio of exchange of the consumer, he drops out of the market, utilizing his purchasing power to secure other commodities. But if the market price is below that which the consumer would be willing to pay to obtain the commodity, he purchases at the market price, and the difference between his subjective ratio of exchange and the objective market ratio of exchange constitutes his "consumer's surplus." The man of means, for example, purchasing his morning paper for a cent, would still purchase if the price of the paper were fixed at five cents, at ten cents, or possibly more. Somewhere in the ascending scale a point would be reached at which even he would drop out of the market. And the difference between this point and the market price of one cent represents his "consumer's surplus."

For true value is not objective, but subjective. The real basis of exchange is the extent to which the article will satisfy the desire of the purchaser. If certain possible purchasers would find more enjoyment in exchanging more of their " consumer's surplus" for certain specialized forms of the particular article a producer makes, rather than spend it for some other articles or services for 


\section{THE DISTRIBUTOR}

which their desire is not so intense, he performs a real social service in supplying them.

The more able distributors turn, though usually unconsciously, to this margin as the basis of a demand for what is virtually a new commodity. That is, they differentiate a product from a staple commodity with an established price and create demand for the modified product upon a new and higher price level.

The means used for differentiation are numerous. Sometimes slight modifications render the commodity better adapted to the use to which it is put. Sometimes niceties of trimming and equipment are utilized. Sometimes a new and more convenient style of package is used. Sometimes the distributor builds up an atmosphere of good taste about the goods, or a reputation for uniform quality which insures the consumer against dissatisfaction. Sometimes the distributor depends upon "service" or special conveniences to the consumer.

Always, however, the aim is to isolate his product from the stock commodity of substantially like nature. And nearly always the distributor utilizes trade marks, brands or trade names to identify his product as a distinct commodity.

He must then convey to those consumers whose subjective ratio of exchange would have led them to pay a higher price for the stock commodity before transferring their demand to other goods, 


\section{MARKET DISTRIBUTION}

knowledge of the existence of his differentiated product at a higher price level. By calling attention to the superior qualities or convenience or constant reliability of his differentiated product, he transfers to it a portion of the demand that formerly found expression in the purchase of the stock commodity.

The marketing of hats furnishes a good illustration of this development. If derby hats were distributed as a staple, unbranded and at a single market price for a given quality, many consumers would pay perhaps $\$ 3.00$ for a staple hat, whose individual ratio of exchange would render them willing to pay more than $\$ 3.00$ for a hat rather than go without. But certain producers have distinguished their hats from the staple hat by their brand. By calling the attention of the consumers to niceties of trimming and finish, and by emphasis upon design, some such producers have built up a demand for their hats at $\$ 5.00$. Now these trademarked hats and the staple, unbranded hats selling at $\$ 3.00$ may be substantially the same commodity, but differentiated by detail modifications. These detail differences render the well-to-do consumer willing to pay a higher price for the trade-marked hat. No doubt the demand for the more expensive hat depends in part upon the sense of security on the part of the consumer that his hat will be of good quality and of proper shape if it bears the name of these producers. This feeling of security forms a 


\section{THE DISTRIBUTOR}

part of the subjective valuation that the consumer places upon the hat. No doubt, too, motives of social emulation sometimes enter in, and the consumer derives a portion of his gratification from the mere fact that he purchases a hat which sells at a higher price than those purchased by his less well-to-do neighbors.

It is of interest to note that other manufacturers of branded hats have in recent years fixed their prices at $\$ 4.00$ and $\$ 6.00$, appealing to consumers upon different price levels from those reached by prior distributors of trade-marked hats. Thus they reach with a $\$ 4.00$ hat a group of consumers not available to the distributors of $\$ 5.00$ hats because their subjective ratios of exchange do not render them willing to pay $\$ 5.00$ for a hat. And with a $\$ 6.00$ hat they draw from the distributors of $\$ 5.00$ hats a part of those consumers whose subjective valuation upon a hat renders them willing to pay more than $\$ 5.00$ for the commodity.

\section{Price Policies Open to the Distributor}

The activity of the more advanced distributors in differentiating commodities has tended to break down the orthodox methods and policies of distribution, and this necessitates an analysis of the possible price policies of the present day merchant-producer.

The producer who today enters the market to manufacture and sell a commodity in competition 


\section{MARKET DISTRIBUTION}

with other producers of substantially identical products has open to him three general price policies. He may adopt one of these to the exclusion of the others, or may use them in combination.

These three policies may be termed, (1) Selling at the market minus, (2) Selling at the market, and (3) Selling at the market plus.

(1) Selling at the market minus is that policy which aims to increase sales by reducing price. The distributor who markets his product at a price range below that established for the identical commodity as sold by other producers not only attracts consumers from other distributors, but also brings into the market as consumers certain of those whose demand was before unexpressed because the price level established for the commodity was above that warranted by their subjective valuation on the commodity.

This policy does not ordinarily involve a differentiation of the product from the stock product of like nature, nor the use of trade marks, brands or trade names. The producer depends upon increased sales to give a reduced proportion of overhead expense and reduced costs of large scale production, thus increasing his area of profit. The producer appeals to the consumer mainly through the difference in price level. Hence, the successful pursuit of this policy in a competitive market over 


\section{THE DISTRIBUTOR}

a long period involves a continuing ability to sell the commodity for less than the price at which other producers of substantially identical products are willing or able to market them.

This policy finds illustration in the selling policy of most department stores. It is the basis of bargain-counter selling. In one class of department store it becomes the dominant policy. Some such stores base their business almost entirely on selling under the market, advertising the purchase of bankrupt stocks and mill clearances as making possible such price cutting.

And in nearly all department stores the manager will at times reduce the price upon a staple commodity below that at which his competitors are willing to sell. His increased sales, arising from custom drawn from his competitors and from new consumers brought into the market, decrease the proportion of overhead expense and enable him to purchase in larger quantities. His larger purchases put him in a position to force the producer to share with him the economies of large scale production. Often, indeed, he is able to take over the entire output of certain factories.

In the department store, moreover, the further element enters that customers attracted to purchase a staple commodity at less than the prevailing price will also purchase other commodities yielding a wider margin of profit. 


\section{MARKET DISTRIBUTION}

The working of this policy, especially as to bringing new consumers into the market, is shown graphically in Chart $\mathbf{I}$.

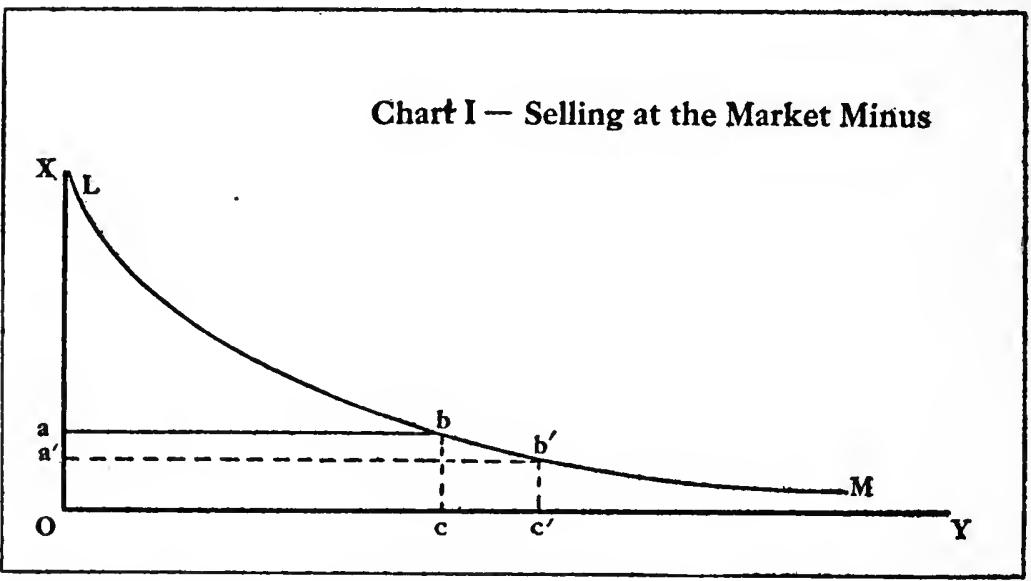

This chart attempts to show graphically the operation on the demand side of the market of the price policy termed "selling at the market minus." On the ordinate $o x$ is laid off a scale of prices for the commodity. On the abscissa oy are laid off the number of purchasers. The arc $L M$ shows the number of purchasers at a given price, growing fewer as the price increases and greater as the price decreases.

Now if oa represents the prevailing market price for the commodity, and oc the number of purchasers at that price, it is apparent that if the price is reduced from oa to $o a^{\prime}$, new consumers will be brought into the market and the number of purchasers at the price $o a^{\prime}$ will be $o c^{\prime}$, a number greater than $o c$.

It is somewhat in this fashion that the policy of selling at the market minus operates, but the chart does not indicate the important element that other producers are selling at a higher level, and hence customers are attracted from them, as well as new customers brought into the market.

(2) Selling at the market has been the policy perhaps most characteristic of our scheme of distribution during the period when the stress was on production. It is still a common policy in the marketing of staple goods.

This policy consists briefly in the acceptance of the market price existing for the commodity as a fixed condition. The producer does not seek to 


\section{THE DISTRIBUTOR}

attract purchasers by maintaining a price level somewhat lower than that at which other producers of the same commodity are willing to sell, nor does he attempt to establish his commodity upon a new and higher price level as a distinct commodity. He recognizes the market price for such a commodity as something objective, and sells his commodity at the established level.

The acceptance of this price policy leaves open to the merchant-producer two general methods of increasing his area of profit. He may devote himself to a reduction in his cost of production by a better organization of his plant, or he may seek to increase his sales, thus giving economies of large scale production and a reduced proportion of overhead expenses.

Examples of the adoption of this policy and the use of the first method of increasing profits are found in the steel industry. The small independent manufacturer often accepts the market price of a given steel product as a fixed condition, sells his "share" of the market, and depends upon reducing his plant costs to increase his profits.

If the merchant-producer adopts this second method, he must, in general, differentiate his product from that of his competitors and build up a demand for his particular product. To do this he must depend upon the same means that would be used to establish his product as a distinct 


\section{MARKET DISTRIBUTION}

commodity upon a higher pricelevel. Trade marks, brands and trade names, coupled with niceties of finish, evenness in quality or more convenient packages, serve as the basis for an increased demand for the commodity upon the same price level as substantially identical products. When selling at the market, superior promptness in delivery may become a factor of great importance in increasing sales.

A recent development in the textile industry illustrates the adoption of the policy of selling at the market, combined with an attempt to increase sales at the market price by a differentiation of the product. Apparently the textile manufacturers who are beginning to brand their goods do not seek so much to establish a new price level for their product as a distinct commodity, as to increase their sales by building up a demand for their commodity as against the product of other manufacturers at the prevailing price level.

Chart II illustrates one phase of this policy. It is intended to bring out the idea that new consumers may be drawn into the market at an existing price level by giving to the differentiated commodity a subjective valuation on the part of the consumer greater than that which he experienced for the stock commodity of like nature. Hence, while the individual's subjective ratio of exchange was too low to lead him to purchase the stock commod- 


\section{THE DISTRIBUTOR}

ity at the prevailing price, he may purchase the differentiated commodity at that price because of his greater subjective valuation upon the latter.

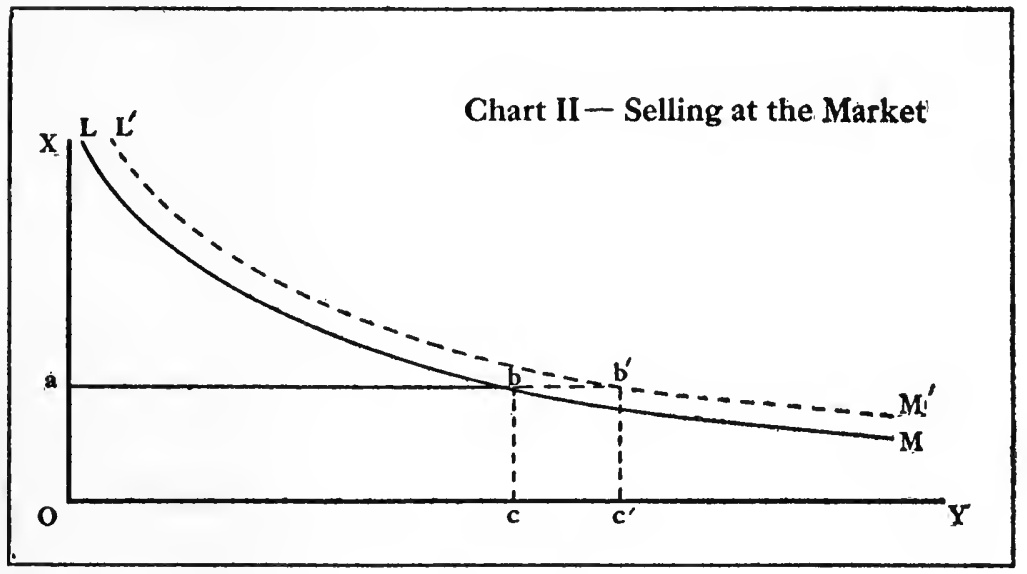

This is an attempt to show graphically the effect of a stimulation of increased demand for a commodity without any increase in the price at which it is marketed.

The ordinate, $o x$, is a scale of increasing price. The abscissa, $o y$, shows the number of purchasers. The arc $L M$ indicates the number of purchasers at any given price, growing less as the price is increased and greater as the price is decreased.

If the established market price is represented by $o a$, the number of purchasers at that price will be represented by oc. If then by stimulating an increased demand for his product, the merchant-producer is able to increase proportionally the number of purchasers at each price level, the demand curve $L M$ will be replaced by $L^{\prime} M^{\prime}$, and at the price, $o a$, a greater number of purchasers, $o c^{\prime}$, will purchase.

This chart does not, of course, show how customers already in the market are drawn from other merchant-producers to the purchase of a differentiated product for which a demand is stimulated at the same price level as the products of the other merchantproducers.

(3) Selling at the market plus is perhaps the most characteristic price policy of modern distribution. The exceptionally able distributors have in recent years turned more and more to this policy. They refuse to accept as a fixed condition the market price for the commodities similar to those which they produce. They isolate their product, and 


\section{MARKET DISTRIBUTION}

establish it, practically as a new commodity, on a different price level.

The whole basis of the policy is the differentiation of a product from other goods of substantially like nature by improvements, minor or substantial, and the identification of the product by trade marks, brands, and trade names. This done, the producer stimulates a demand for his product by calling attention to stability of quality, niceties of finish, improvements in package or like modifications. He appeals to that portion of the consuming public whose subjective valuation upon the stock commodity has left them a so-called " consumer's surplus " over the market price. The differentiated commodity is established on a new and higher price level, and is to all intents and purposes a new commodity.

It is this policy that forms the most severe test of the ability of the distributor. To succeed he must have an unusual equipment, including knowledge of human nature, of the psychological organization of the individual consumer, and must be able to give proper weight to such motives as social emulation and all the varied factors that enter into the subjective ratio of exchange of the consumer.

This policy has already been illustrated by examples from the hat trade. Examples are all about us today and further illustration is here unnecessary. 


\section{THE DISTRIBUTOR}

Chart III shows graphically the operation of the price policy termed " selling at the market plus."

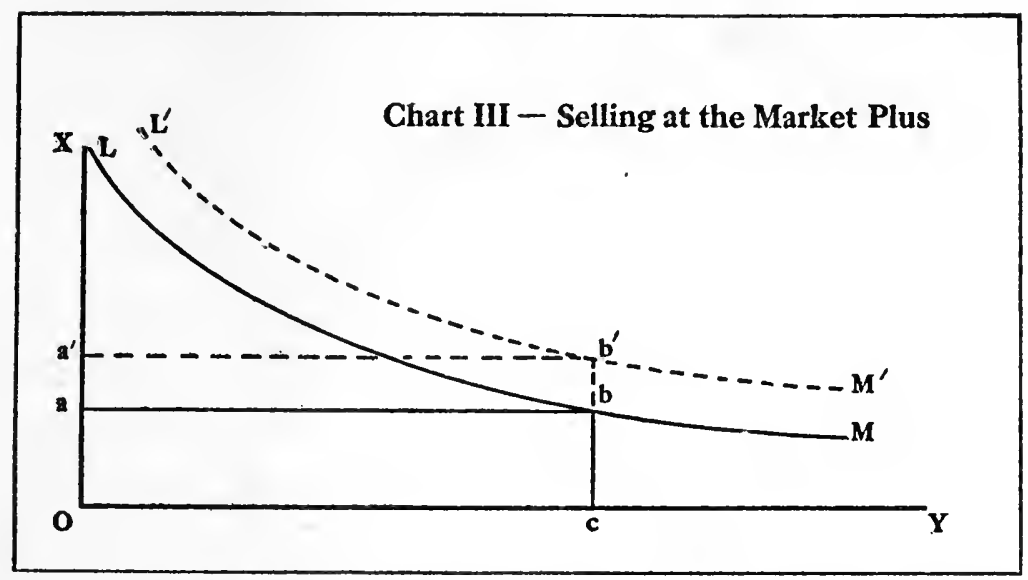

This chart illustrates the effect of the price policy termed " selling at the market plus." On the ordinate $o x$ is laid off a scale of prices for a staple commodity. The abscissa oy shows the number of purchasers.

The demand curve $L M$ indicates the number of purchasers at a given price, growing less as the price increases and greater as the price decreases. Then if oa represents the market price of the staple commodity, $o c$ will represent the number of purchasers. Now if the merchant-producer differentiates his product from the staple commodity and stimulates a demand for it, the effect is to increase the number of possible purchasers at each price level. Thus the demand curve $L M$ is replaced by the demand curve $L^{\prime} M{ }^{\prime}$.

Obviously the merchant-producer may dispose of the differentiated product at a price $o a^{\prime}$, higher than the price $o a$, without reducing the number of purchasers, $o c$. In other words, be can profit by the increased demand through raising his price rather than by increasing his sales.

\section{The Differentiation of Commodities}

It is apparent that the process we see going on as a result of the increasing adoption of the policy of selling at the market plus, involving an increasing differentiation of commodities at various price ranges, is closely analogous to the creation of new commodities. When the hat trade splits up into a number of isolated brands, practically distinct 


\section{MARKET DISTRIBUTION}

commodities at different price levels, the situation is from a social point of view little different from that arising from the creation of new commodities which are not merely modifications of pre-existing commodities.

If the safety razor be regarded, as it properly may be, as a new commodity rather than as a modification of the old style razor, it provides us with an opportunity to examine the social justification for the creation of a new commodity.

When the first widely-advertised safety razor was put upon the market at $\$ 5.00$ a considerable margin of profit was left the producer. It was often said at the time that the actual cost of manufacture of that razor was less than $\$ 1.00$. Now this wide margin made possible an extensive advertising campaign. The new device was brought to the attention of the entire consuming public. Everyone, whether in the large centers or remote districts, learned of the safety razor and its uses. Great numbers purchased the razor because the subjective valuation which they placed on the commodity, when it was brought to their attention, exceeded the price asked. The large reward received by the distributor may perhaps properly be regarded as compensation for bringing about a better adjustment to meet human needs.

Today the safety razor demand is well established and those consumers whose individual ratios 


\section{THE DISTRIBUTOR}

of exchange do not render them willing to pay $\$ 5.00$ for a safety razor are able to gratify their conscious need at prices ranging as low as twenty-five cents, owing to numerous producers entering the market with safety razors at varying price levels.

Now when the producer of a commodity already marketed by other producers sets off his commodity from others of like kind, and by sometimes even minor modifications and improvements is enabled to build up a demand for it on a higher price level than that existing for the stock commodity of like kind, he, too, has made possible a more accurate adjustment in supplying human wants, and has brought the possibility of this more accurate adjustment to the attention of consumers. The purchaser of a trade-marked hat at $\$ 5.00$ would buy a staple hat for $\$ 3.00$, if the $\$ 5.00$ hat did not give him equal or greater proportional gratification, taking into account the differing objective ratio of exchange. Obviously, the consumer who buys a trade-marked hat does so because he prefers to pay $\$ 5.00$ for such a hat rather than $\$ 3.00$ for an unbranded stock hat. To say that he ought not to be willing to pay the additional $\$ 2.00$ for the differentiated product because the modifications are not substantial is to attempt to substitute for the subjective valuation of the consumer an external social standard as a basis of exchange. The more highly differentiated the scale of commodi- 


\section{MARKET DISTRIBUTION}

ties is, the more accurately will it be possible for the individual consumer to satisfy his varied material wants.

The distributor who is successful in establishing a differentiated product as a distinct commodity on a new price level is, for a time, in the position of having a monopoly as to the differentiated commodity. Such competition as he has is the indirect competition of the staple commodity of like nature. His monopolistic position often enables him to obtain temporarily a margin of profit disproportionate to the actual improvements in the differentiated product as compared with the staple commodity of similar nature. This, again, may be justified as a reward for enterprise in making possible a more exact adjustment of goods to the wants of the consumer. And in the long run, the large percentage of profit will decrease as other producers follow his example and differentiate their products from the staple. The rise of competition at the new price level will ultimately force in the competing differentiated commodities the substantial improvements warranted by the higher price.

Where the differentiation of a product from staple articles of like nature is not aimed at establishing a higher price level, but rather at an increase of sales at the prevailing price level, an indisputable social gain appears. Manufacturers 


\section{THE DISTRIBUTOR}

of trade-marked goods inevitably find it necessary to put stress upon quality and to so organize production that this quality shall be kept uniform. The manufacturer of unbranded goods on the other hand does not feel the sense of responsibility to the consumer that exists when the goods reach the consumers under the producer's name. The manufacturer of unbranded goods makes them generally to sell to the middleman; not primarily to satisfy the consumer since he has no certain way of profiting by this satisfaction. 


\section{CHAPTER III}

\section{METHODS OF DISTRIBUTION}

THE general market problem which confronts the business man has been roughly analyzed. The differing modern price policies have been outlined. Something has been said as to the social justification of the increasing differentiation of goods involved in certain price policies. We now may examine the methods employed in selling.

In the early stages of our industrial history, sales were made in bulk. At all stages in distribution, the purchaser saw the actual goods before the sale was made.

Later, sale by sample appeared. The purchaser bought goods represented to be identical with the sample he was shown. The introduction of this method of sale was necessitated by the widening of the market and was made possible by improvement in commercial ethics and by increasing standardization of the product. The purchaser must have confidence not only in the honest intention of the producer to furnish goods identical with the sample, but also in his ability to produce identical goods. Hence, increasing uniformity in product 


\section{METHODS OF DISTRIBUTION}

through machine methods of manufacture was a factor in the increase of sale by sample.

Sale by description is the most modern development in distribution. An even higher ethical standard is required than for sale by sample. Moreover, sale by description requires a higher level of general intelligence than sale in bulk or sale by sample. Sale by description in its modern development is, in a sense. a by-product of the printing press.

All three methods of sale are in use in modern commercial life. The consumer still purchases a large part of the commodities which he uses under a system of sale in bulk. He sees the goods before he buys them. The middleman, buying in larger quantities, generally purchases from sample. But sale by description becomes each year of increasing importance at every stage in the system of distribution. Even where the purchaser actually sees a sample or the goods themselves before the sale is concluded, the method of sale by description has in many cases previously been used to create in him a demand for the commodity. Sale by description is found not only in goods for consumption, but also in the sale of machinery and like commodities. So rapid has been the development that Mr. Edison, the inventor, has said that he expects the store of the future to be upon the slot machine plan, all the goods being sold by de- 


\section{MARKET DISTRIBUTION}

scription. That even the conception of such an arrangement can arise is significant.

The root idea in sale by description is the communication of ideas about the goods to the prospective purchaser by spoken, written, or printed symbols. This takes the place of the sight of the goods themselves or a sample of them. It is obvious that this requires that the purchaser shall have sufficient intelligence to grasp readily ideas either through spoken, written, or printed symbols.

The use of the term "symbols" rather than " words" is necessitated by the fact that photographs and sketches are today an important feature of sale by description. A photograph of the commodity often serves the purpose of pages of verbal description.

The ideas to be conveyed to the prospective purchaser in sale by description are such as will awaken an effective demand for the commodity in question. The awakening of demand is the essential element in selling. It must be remembered, however, that the distributor has the further task to provide for the possibility of gratifying the demand by making the goods physically available to the buyer. In sale in bulk this problem merges with the selling since the goods are physically present when the sale is made, while in sale by description the physical distribution of the goods is a distinct problem from the awakening of 


\section{METHODS OF DISTRIBUTION}

demand. And it is a problem that requires equal attention, for it is useless to awaken demand unless the goods to satisfy it are made available.

\section{Available Agencies for Seluing}

As demand creation is the initial step in distribution, it is necessary to consider the agencies for this purpose available to the merchant-producer. There are three general agencies to be considered: (1) middlemen, (2) the producer's own salesman, and (3) advertising, direct and general. The business man faces the problem of what agency or what combination of agencies is the most efficient for the creation of demand and the physical supply of his particular commodity.

The method of sale adopted will largely govern the choice of agency to be employed. If the sale is to be in bulk, the purchaser viewing the actual goods before the purchase is made, distribution through a series of middlemen is generally most feasible. However, such sale in bulk through the producer's own salesmen is possible in some cases. Small household appliances are often sold in this manner by door-to-door salesmen.

If sale by sample is the general method adapted to the commodity in question, middlemen or salesmen will often be the more desirable agencies. Many commodities are distributed through middlemen, the sale at each stage in the process being 


\section{MARKET DISTRIBUTION}

by sample save for the final stage from retailer to consumer, where the sale is in bulk. Direct salesmen, perhaps in the majority of cases, sell from sample. And even selling by direct advertising alone is in some cases adapted to a method of sale by sample. Thus the distributor by mail of a commodity which is not bulky may enclose in his direct advertising material a sample of the commodity.

Where sale by description is used exclusively, advertising, direct or general, is likely to be the most efficient agency. Yet here again it is possible, though generally not economical, to distribute a commodity through a series of middlemen and yet the sale at each stage be accomplished by description. And the use of salesmen in selling by description is common, as where heavy machinery is sold by the use of photographs, or hardware and like commodities from catalogues.

The number of possible combinations of methods and agencies renders the problem of the producer-merchant an intricate one. It will be seen that he has a difficult task in analyzing the market with reference to his goods, and in working out that combination of methods and agencies which will give him the most efficient system of. distribution.

It is necessary, however, to turn to a brief consideration of the position of the middleman as a part of the evolution of organized distribution. 


\section{METHODS OF DISTRIBUTION}

The history of the middleman's functions has not yet been adequately studied, but a tentative suggestion may be made in default of the fuller study which the subject deserves.

\section{The Middleman in Distribution}

The middleman is a by-product of a complex industrial organization. Chart IV shows in rough outline the evolution of the middleman from the early period when producer dealt directly with consumer to the appearance of the orthodox type of distribution (late in the eighteenth century and in the first quarter of the nineteenth century) when a complicated series of middlemen existed. It should be noted that this chart represents the typical case of the domestic product rather than that of imported commodities.

In the more primitive barter economy, the producer deals directly with the consumer, and middlemen take no part in the transaction. In the medieval period, as the handicrafts become specialized occupations under a town-market regime, the producer is a retailer and sells directly to the consumers. Then as the market widens, a division of labor is necessary and the merchant appears as an organizer of the market. The handicraftsman becomes a steady worker, no longer concerning himself with selling. He becomes in many cases practically an employee of the merchant-retailer, 


\section{MARKET DISTRIBUTION}

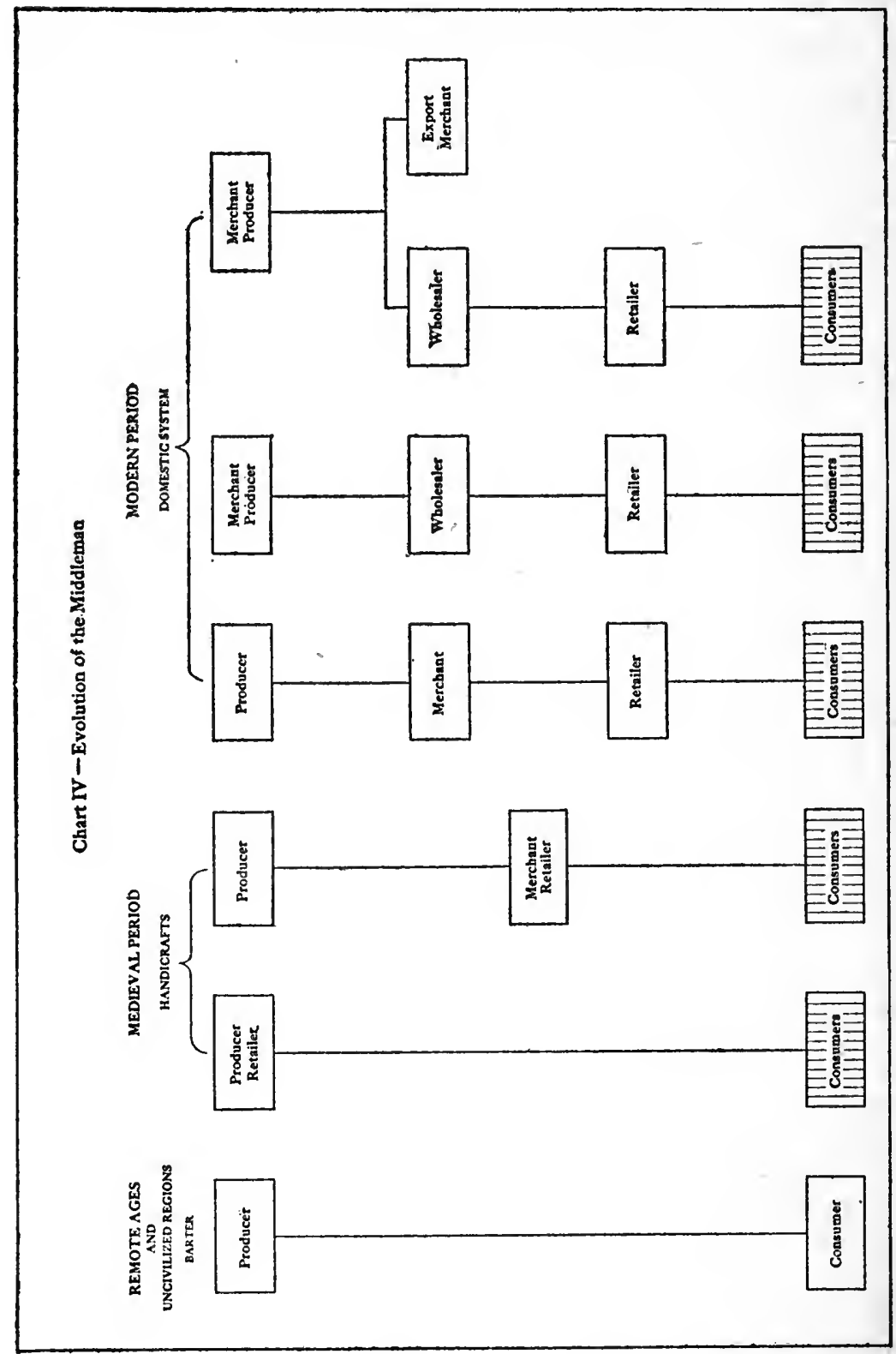




\section{METHODS OF DISTRIBUTION}

who provides the stock and bears the risk. The merchant takes the finished goods from the producer and sells them to the consumer.

Steadily the market widens until we find a national market. The merchant is no longer a single intermediary between the producer and the consumer. The merchant who takes the goods from the producer disposes of them to retail merchants who in turn distribute them to the consumer. After a long period, we find the producers gradually strengthening their financial position, and freeing themselves from the control of a single merchant. They become merchant-producers. They assume the burden of production, and dispose of the product to various wholesalers who in turn sell to retailers, and they to the consumers. As a world market appears, the producer disposes of a part of his product to the export merchant.

In the early days of the factory system, shown in Chart V, we find that the producers have lost their character as merchants and are devoting themselves to the problems of production. The pressure on production has continued, and with the increasing intricacy of industry producers have found it necessary to concentrate their attention on production. The selling agent appears as a link in the chain of distribution to relieve the producer of the task of selling his product. The selling agent undertakes to sell the entire output 


\section{MARKET DISTRIBUTION}

of the producer. He distributes it among wholesalers, who in turn distribute it to retailers, and the retailers to the consuming public.

This may be termed the orthodox type in distribution, a type almost universal in the early decades of the nineteenth century, and still common, as in the textile industry in New England.

Just as the long period of development from a system of barter economy to the early decades of the factory system showed a continuous tendency for increase in the number of middlemen intervening between the producer and the consumer, so recent years have shown a growing tendency to decrease the number of successive steps in distribution. The tendency is apparent in nearly every industry and has been clearly marked in recent years.

Under the orthodox type of distribution, with numerous middlemen intervening between the producer and the consumer, the producer's position is not an advantageous one. The fixed charges under which he operates make it almost imperative that he operate continuously. The outlet for his goods, however, is controlled by middlemen. Hence the middleman is able to exert pressure upon the producer and force a narrowing of his margin of profit. It was on account of this pressure and in order to free themselves from it that the stronger producers (merchant-producers now) sought to 


\section{METHODS OF DISTRIBUTION}

find ways of going around the middlemen, and establish more direct contacts with consumers.

Chart $\mathrm{V}$ is an attempt to show diagrammatically the development of this apparent tendency to decrease the number of middlemen. By the use of salesmen going directly to the wholesaler and by advertising directed to the retailer the producer has displaced the selling agent in many cases. Sometimes the advertising is directed not only to the retailers but also to the wholesalers. To strengthen his position still further, the producer will often use advertising directed to the consumer to build up a demand for his product. This involves the development of a product differentiated by trade mark, brand, or trade name. When the producer thus directly builds up a demand among consumers, he often takes the further step of sending his salesmen to the retailer, thus omitting the wholesaler entirely from his system of distribution.

The most extreme step in the process is the complete elimination of middlemen, and the sale direct from the merchant-producer to the consumer, either by advertising alone or by salesmen supplemented by advertising. Manufacturers of specialties have largely adopted this scheme of distribution and the enormous growth of the mail order business in recent years gives evidence that in some lines of distribution apparently there are economies in this system. 


\section{MARKET DISTRIBUTION}

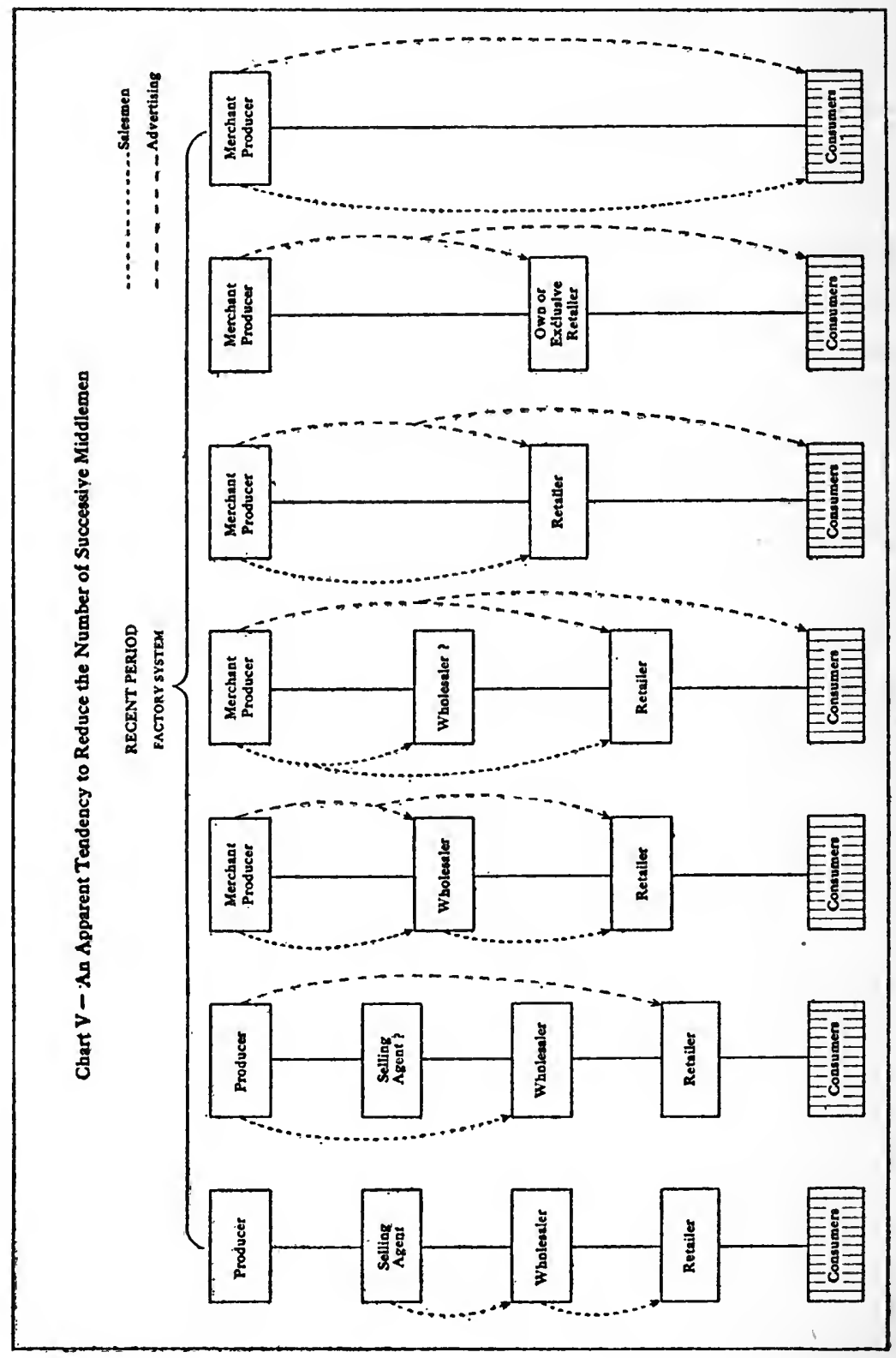




\section{METHODS OF DISTRIBUTION}

The tendency to decrease the number of middlemen is one of the most characteristic features of modern distribution. It promises to show much greater development in the future if present economic conditions substantially continue. The attempts of associations of retailers to check the growth of direct selling have thus far not been successful. In their desire to force the manufacturer to dispose of his product through regular trade channels they have at times taken concerted action to discourage direct sales. But our national and state laws prohibiting combinations in restraint of trade prevent effective agreements of this sort. And the advantages of direct selling in some lines render the producer willing to incur the disfavor of the trade.

It should be noted, however, that changed conditions might give the middleman increased importance. Suppose, for instance, that the protective tariff system of the United States were to be swept away and free trade instituted. The middleman could then draw upon the foreign producer for supplies of unbranded staple goods, which might serve to increase his importance as a link in our system of distribution. While this would perhaps tend to increase the number of successive middlemen in some lines, it is probable that when the foreign producer in turn was subjected to pressure by the middleman, he, too, would 


\section{MARKET DISTRIBUTION}

tend to go around him and deal directly with the consumer.

\section{The Functions of the Middleman}

To understand what seems to be a present tendency to go around the middleman as well as to consider the problem of the merchant-producer with reference to the use of middlemen in distribution, it is necessary to analyze the functions performed by the middleman. Roughly the general functions may be listed as follows:

1. Sharing the risk.

2. Transporting the goods.

3. Financing the operations.

4. Selling (communication of ideas about the goods).

5. Assembling, assorting, and re-shipping.

These functions were at first taken over by areas; that is, each successive middleman in the series took over a part of each function. Each took the risk of destruction of the goods while he held title. Each took the risk of credit losses. Each took a share in the transportation of the goods along the route from the producer's stock room to the hands of the consumers. Each took a part in financing the entire operation. Each had a part in the selling, disposing of the goods he purchased to succeeding middlemen and finally to the consumer. And each finally took a part in assembling, assort- 


\section{METHODS OF DISTRIBUTION}

ing, and re-shipping the goods to make them physically available to the consumer.

But at a relatively early date a taking over of these functions by kind instead of by area appeared. Today we have what may be termed functional middlemen in the insurance companies, direct transportation companies, and banks.

The insurance company is in a real sense a middleman in distribution. When it insures the producer against loss of goods by fire, against credit losses, and the like, it is taking over the function of risk formerly shared by successive middlemen. Today the insurance company will assume practically the entire element of risk. It is possible, for instance, for a large department store to insure against unseasonable holiday weather. The insurance company differs from the ordinary middleman in that it takes over one function as such rather than portions of a number of functions.

So improvements in direct transportation have enabled the producer to turn to a functional middleman to convey the goods to the consumer. The transportation companies and the express companies are in a true sense middlemen in distribution, though they perform but one of the functions formerly shared by the successive middlemen who took over functions by area. The physical conveyance of the goods to the consumer was formerly one of the most important functions per- 


\section{MARKET DISTRIBUTION}

formed by a series of middlemen. Hence every improvement in the agencies of direct transportation has tended to modify existing systems of distribution. It is this fact that gives importance to the projected establishment of a parcel post. ${ }^{1}$ So the function of financing the operations has largely been taken from the regular middleman. In former times the middleman took his part in the burden of finance in addition to his other functions. It is true today in the textile industry in New England that the selling agent is as much a banker as a mere agency for the sale of the goods. This is accomplished, however, by the selling agent's endorsing the commercial paper of the producer, giving a two-name paper acceptable by savings banks in that region, and hence making it possible to tap an important reservoir of capital as well as to secure a lower rate of interest.

In most industries today the bank, as a functional middleman, cares for the element of finance in the operations of distribution. By advancing on goods and on commercial paper, it largely absorbs the function of finance in distribution.

1 Since the first appearance of this essay, the parcel post has been put into successful operation in all parts of the United States. It is too early as yet to forecast its effect upon our present system of distribution. It is being employed, however, by producers and distributors of all classes (local retail merchants as well as catalogue houses) to maintain direct and constant touch with consumers - particularly with farmers and dwellers in sparsely populated districts. 


\section{METHODS OF DISTRIBUTION}

Legislation providing for an asset currency based on commercial paper might widen the range of the banks' activity in the commercial field. ${ }^{1}$

Another development has lessened the financial dependence of the producer. The application of the corporate form to industrial organization has made it possible to draw together larger bodies of operating capital and hence to place the producer in a stronger financial position.

As a result of the development of functional middlemen, ready to assume the risk, transport the goods, and finance operations, the importance of the middleman for these functions has diminished. There remain the functions of selling (the communication of ideas about the goods) and of assembling, assorting, and re-shipping. Here the middleman is of most importance today.

Under the orthodox type of distribution which we have considered above, the producer is not in any sense a merchant. The selling agent takes upon himself the initial distribution of the entire output. He sells the goods to the wholesaler. The basis of the sale is that the wholesaler can dispose of the goods at a profit to the retailer. The wholesaler in turn sells the goods to the retailer.

1 The establishment of the Federal Reserve Bank system, since this chapter was written, has produced this effect of a more elastic currency based on commercial paper and trade acceptances, with a corresponding gain in credit resources and banking power. 


\section{MARKET DISTRIBUTION}

Again the inducement to purchase is not primarily quality or service but the opportunity to re-sell at a profit to the actual consumer. Only when the retailer comes to sell to the consumer does stress fall upon quality and service, as the inducement to the sale. Hence the ideas to be conveyed to the prospective purchaser to create in him a demand for the goods vary at different steps in the complicated process of distribution, because of the different points of view of those who buy for resale and those who buy for consumption. Price and saleability are the all-important factors to the middleman; quality and service are as important to the consumer as price.

The tendency of the orthodox system of distribution of unbranded commodities is to turn the energies of the producer primarily toward lowering the cost of production and hence the price which he is able to offer the middleman. The influence of satisfaction or dissatisfaction on the part of the consumer comes to him only indirectly through a chain of middlemen. Moreover, where the goods are undifferentiated by trade mark or trade name, their identity is often completely lost in the successive stages of distribution. Even the retailer in many cases concerns himself rather with saleability than with ultimate satisfaction to the consumer. Hence, only marked defects in quality are likely to be brought to the attention of the producer. 


\section{METHODS OF DISTRIBUTION}

Thus the producer loses the touch with the consumer which will assist him to make improvements in quality and service in his goods. His attention is not forced upon those elements in the commodities which he manufactures. So under the orthodox type of distribution of unbranded commodities the standard of the producer tends to become saleability rather than satisfaction to the consumer.

Suppose, however, the producer does give conscious attention to elements of quality and service in his goods which render them more desirable from the standpoint of the ultimate consumer than other goods of like nature. Before the knowledge of these superior points reaches the consumer it must be passed along by two or more middlemen, who are not for the most part primarily interested in quality or service and no one of whom ordinarily gives undivided attention to the single commodity. The ideas that the retailer must communicate to the consumer to create in him a desire for the commodity are not the ideas which the wholesaler conveyed to the retailer to induce him to purchase.

Hence a producer who has added to his goods special advantages in quality or service finds it difficult to convey to the consumer through a chain of middlemen the precise ideas about those advantages that will lead the consumer to demand his 


\section{MARKET DISTRIBUTION}

goods in preference to those of another manufacturer.

These considerations render the increasing communication of ideas about the goods by the producer directly to the consumer an innovation of great social significance in our scheme of distribution. The producer is forced to study the consumer's wants and to adjust his product to them. $\mathrm{He}$ can no longer devote his attention exclusively to cost. He realizes that the consumer's satisfaction depends on the quality of the goods and the service that they render. These become to him considerations as important as that of cost. Moreover, when he works out in his product some improvement in quality or service which more adequately adapts the commodity to the wants of the consumer, he is able to convey to the consumer precise and accurate knowledge of these improvements and to reap in increased demand for his product the reward for his efforts. Direct selling means, of necessity, a better adjustment of production to the needs of the consumer. Goods are being made to satisfy rather than to sell.

Obviously, direct selling depends on a differentiation of commodities. The producer can effectively communicate ideas about his goods directly to the consumer only when the consumer is able to identify the goods. Where the physical distribution is through retail stores, the goods must be 


\section{METHODS OF DISTRIBUTION}

distinguished from other goods of like nature by trade mark, brand or trade name, or the direct selling efforts of the producer are wasted.

The advantages of direct communication of ideas about the goods by the producer to the consumer as just outlined coöperate with the desire of the producer to escape pressure exerted by the middleman. As a result we find in the past half-century and especially in the past decade a rapid adoption by producers of agencies for direct communication of ideas about the goods to the consumer. This means that another function formerly divided among middlemen is being taken over as a function entire. Newspapers, periodicals and other advertising agencies may hence be termed functional middlemen, as were the insurance companies, the transportation companies and the banks. And with the rise in importance of these functional middlemen the position of the old type of middlemen is again weakened.

We have still to discuss the functions of assembling, assorting, and re-shipping. These functions render the goods physically available to consumers so that an aroused demand can be gratified. Here the middleman retains for the most part his importance. To be sure, we find direct shipments from producer to consumer steadily increasing. This is to be expected as a consequence of the direct communication of ideas about the goods by 


\section{MARKET DISTRIBUTION}

the producer to the consumer. But in the more important lines today the consumer still depends on the retail store for the supply of the goods for which a demand has been stimulated and the retail store in general turns for its supply to the wholesaler.

The problem of the distributor is two-fold: (1) to arouse a maximum of demand, and (2) to supply that demand with a minimum of leakage. The second phase of the problem involves the elements of time, convenience and service. If the demand which has been aroused among consumers is to be fully utilized, it must be made possible for them to obtain the goods promptly when the demand arises.

It must be convenient for them to obtain the goods. In many cases, certain collateral services such as instruction, demonstration and repairs must be given. It is here that the retailing middleman still retains his importance in most lines. If, when a conscious demand has been raised for a certain food product by the direct communication of ideas about the goods by the producer to the consumer, the latter is unable to find the product at a convenient grocery store, the aroused demand is likely to be ineffective. Hence the producer will often continue to distribute his product through the regular trade channels after taking over the selling function by directly communicating ideas about the goods to the consumer. Distribution by mail 


\section{METHODS OF DISTRIBUTION}

order and direct shipment by the producer have thus far proved applicable only to certain commodities and in reaching certain sections and classes. For many lines and in many districts the middleman is as much a social necessity as ever.

When a producer begins to communicate ideas about goods directly to the consumer to arouse a demand, it is apparent that the middleman is performing only a part of the functions he previously performed. On strict economic grounds the margin of profit of the middleman should be reduced in proportion to the reduction of his functions.

In compensation for this reduced margin of profit on each sale, the middleman secures more frequent turnovers due to the selling efforts of the merchant-producer. But the middleman is often slow to see this compensating feature. He usually resists any attempt to reduce his discount because the producer has taken over the selling function. If his compensation per sale is reduced he may refuse to handle the article. It is fair to say, however, that many wholesalers and retailers appreciate the possibilities of more rapid turnover of stocks and are adjusting themselves to the changed conditions.

Now if the producer takes over the selling function and does not reduce the discounts allowed the middleman, the middleman is being paid for a function he no longer exercises. And ultimately 


\section{MARKET DISTRIBUTION}

this must come out of the pockets of the consumer. $\mathrm{He}$ is compelled to pay twice over for the exercise of a single function.

The opposition of middlemen to reduced compensation when their functions are taken over presents a difficult problem to the producer. Often the producer postpones taking over the function of selling by direct communication of ideas to the consumer because he sees that he must continue to allow the middleman compensation for that function if he is to continue to use the middleman for the physical distribution of the goods. Sometimes the producer chooses to establish branch stores and so eliminate all middlemen from his system of distribution. This, however, is generally possible only in large centers of population and applicable only to certain classes of goods. The system of distribution through branch stores is illustrated in its application by certain large producers of trade-marked shoes.

It is, however, feasible in many lines of trademarked goods to take over the assorting, assembling, and re-shipping function of the wholesaler rather than to continue to compensate him for the selling function no longer performed. For example, one large paint manufacturer, who stimulates a demand for his branded paints and varnishes largely by direct communication of ideas about the goods to the consumer and to the retail 


\section{METHODS OF DISTRIBUTION}

paint dealer, found it desirable to eliminate the wholesaler from his scheme of distribution. $\mathrm{He}$ finds in branch houses certain marked advantages. (1) He is able to obtain the entire time of trained men, devoted solely to the handling of his products. (2) He obtains a direct contact with the retail dealer, who he finds prefers on the whole to buy directly from the manufacturer. (3) $\mathrm{He}$ is enabled to carry larger and better assorted stocks than the wholesaler would be willing to carry.

In his experience the credit losses are less when the wholesaler is eliminated. (5) He maintains better control of general policy and prices. The larger capital required for a system of branch houses is an objection of decreasing importance owing to the rapid increase in the available capital fund and its greater fluidity. And the increased need of managerial ability is being met by improved systems of training men for managerial responsibilities.

This rather lengthy analysis of the position and functions of the middleman in distribution is still incomplete. Factors not of an economic character enter. The business man seldom faces a problem on purely economic grounds. There is always a human element to be considered, arising from the character of transactions as they exist in actual commercial life. One does not buy of a dealer solely upon narrow economic grounds. Social and personal considerations play their part. Hence, 


\section{MARKET DISTRIBUTION}

when the business man considers the position of the middleman in his own scheme of distribution, his problem is complex. Its solution is likely to be found in the rise of a class of efficient and progressive middlemen who will take advantage of the producer's selling efforts by effecting more rapid turnover of stock, and will provide the necessary physical distribution of the goods at a reduced percentage of profit on the unit sale but with an increased profit on the greater volume of merchandise passing through his hands.

\section{The Producer's Salesman in Demand Creation}

A less detailed analysis than was necessary in the case of the middleman will be required for the salesman. The primary function for which salesmen are used is the communication of ideas about the goods to the prospective purchaser; that is the selling function.

The salesman, in the sense of a man sent to prospective purchasers, generally sells from sample. In some few cases the sale may be in bulk, the salesman showing the prospective purchaser the actual goods to be purchased. And as has been suggested, the salesman may sell entirely by description, merely showing the prospective purchaser pictures of the goods, as in selling from catalogue.

When the producer finds it desirable to go around a middleman and to sell directly to a sub- 


\section{METHODS OF DISTRIBUTION}

sequent middleman or to the consumer, he may use for the selling function either his own salesmen or advertising, or the two in combination.

When one considers the salesman as an agency for sale by description in contrast with advertising, direct or general, one must take into account the human element again. Advertising has the obvious advantage that you can convey exactly the idea you wish to convey in the form you wish to convey it. It lacks, however, the personality and the timeliness of the salesman's visit; it lacks adaptability, the opportunity to use the mood of the customer and all the various human factors that add to the salesman's effectiveness.

More than this, when the salesman has aroused in the prospective purchaser a demand for the goods in question, he is on the ground to close the sale at once. In the case of advertising, the demand aroused must, in general, be strong enough to lead the prospective purchaser to go to some trouble before he obtains the actual goods. Hence a less intensive demand may be more immediately effective in the case of the salesman than when advertising is concerned.

It should here be emphasized that the analogy between direct salesmen and advertising is very close. Each agency is largely used to enable the producer to take over one function of the middleman, that is, the selling function. And in each 


\section{MARKET DISTRIBUTION}

case the root idea is the same. The producer seeks to communicate to the prospective purchaser through one or the other agency, or a combination of the two, such ideas about the goods as will create a conscious demand for them. The direct salesman and advertising are different modes of accomplishing the same end.

\section{Advertising as an Agency in Distribution}

Advertising in the modern commercial sense is of comparatively recent development. Only in the middle of the nineteenth century did it commence to be of real importance in the commercial world. And as in its early extensive use the sale of proprietary medicines of doubtful value predominated, it was held at first in somewhat bad repute as an agency in demand creation. This notion lingers among many economists, who are satisfied casually to condemn advertising under the name " puffing," and who fail fairly to analyze its position as an agency in our scheme of distribution.

That there are evils and abuses in connection with advertising today may be frankly admitted. It is a new economic agency, and ignorance of its true function causes wasteful use. Moreover it lends itself to conscious misuse. So the factory system carried with it evils which were far greater a century ago than today. And just as the factory system, by gathering together large bodies of 


\section{METHODS OF DISTRIBUTION}

workers, drew attention to evils which existed unnoticed under the domestic system of manufacture, so advertising tends to bring into the lime-light of publicity certain evils which existed as well in sale through other channels. But these are rather undesirable and non-essential incidents than anything fundamental to the thing itself. The evils must be recognized and combated, but should not cloud the fact that advertising is today an element of tremendous importance in our economic organization. The steady and remarkable increase in advertising evidences its efficiency as a selling force. In the United States we are expending annually upon advertising, in its inclusive sense, not less than a billion dollars. This is a cold economic fact which renders advertising worthy of serious analysis.

Advertising is a necessary consequence of sale by description. It has been pointed out that so long as the prevailing code of commercial ethics made sale in bulk the only practical method, the middleman was an indispensable selling agency. As business morals bettered and manufacturing methods improved so that a standardized product could be turned out, sale by sample appeared. Then it became possible for the producer to send his own salesmen with a sample to the prospective purchaser instead of being dependent solely upon the selling efforts of a middleman. And then, 


\section{MARKET DISTRIBUTION}

when sale by description appeared, with an even higher code and a higher level of general intelligence, a third selling agency became possible.

In advertising, as in selling through salesmen, the producer communicates ideas about the goods to the prospective buyer to create in him a demand for the goods. While the purchaser insisted that he see the actual goods before purchasing, sale by advertising was impracticable. While he still required to be shown a sample of the goods, advertising was not in most cases feasible. But now that the general average of intelligence enables the prospective purchaser to gain an idea of the goods without seeing them and without seeing a sample, and now that the prevailing code of business ethics is such that the prospective buyer feels that he may rely upon the description given him, advertising becomes in many lines the most economical agency for the exercise of the selling function. Even where the actual sale is made by salesmen from sample, advertising is used as a supplementary agency to build up a demand which the salesman crystallizes. And sale by advertising alone may be applied today even where the purchaser demands to see the goods before concluding the purchase, by sending the goods to him on approval.

Not only is the modern development of advertising dependent upon the possibility of sale by 


\section{METHODS OF DISTRIBUTION}

description, but it also depends upon the increasing differentiation of commodities by trade marks, brands, and trade names. As before suggested, the producer cannot profitably convey to the consumer ideas about a certain food product which will build up a demand for that product, unless the consumer is able to identify the particular product when he goes into the grocery store to purchase it.

Advertising, then, may properly be regarded either as a substitute for middlemen and salesmen or as auxiliary to them in the exercise of the selling function. Owing to the rise of sale by description and the increasing differentiation of commodities, it tends to displace in whole or in part these other agencies in many lines of distribution because it is a more economical and efficient means of communicating ideas about the goods to the consumer.

Advertising, in the sense here used, may be defined as the communication to possible purchasers by written or printed symbols of ideas about the goods, designed to create a demand for the goods. In this broad sense it includes not only selling letters and circulars, but newspaper and periodical advertising, bill-boards and window cards, electric signs, street-car advertising, catalogues and all the varied forms of modern commercial publicity. A rough classification is made between general and direct advertising. General advertising includes newspaper and magazine advertising, bill-boards, 


\section{MARKET DISTRIBUTION}

electric signs, street-car advertising and the like, aimed at the general public or some section of it. Direct advertising is used in reference to the sending of selling letters, circulars, or catalogues to the persons whose names appear on a mailing list and to influence whom the material sent is specially adapted. This classification is of some importance in discussing advertising as an agency in distribution.

We cannot here attempt an adequate discussion of modern advertising in its varied phases. And it is perhaps not necessary, so much is it today forced upon the attention of each of us. To realize the machinery now provided for the direct communication of ideas about goods, one has but to consider that a single publishing company today reaches through two magazines about three and three-quarters million families; that there were in this country in 1911, according to the Statistical Abstract, 22,806 newspapers and periodicals. A fair measure of the development of advertising in recent years is found in the rapid progress of inventions to facilitate advertising, - photography, the half-tone process of reproducing photographs and drawings, the three-color processes for more exact and convincing reproduction, the cheapening and perfecting of papers, inks, and printing.

Advertising is now being extended to fields where its use not many years ago was undreamed 


\section{METHODS OF DISTRIBUTION}

of. Ten years ago an advertising man would have said it was impractical to advertise papers; today enormous sums are expended on general advertising of papers for writing and printing. Advertising is even used today in fields other than commercial distribution. The railroads annually buy large quantities of newspaper space in which to present facts which will help the public to a better understanding of their situation, their attitude and their needs and thus forestall possible adverse legislation. And advertising by the railroads to secure passenger and freight traffic has reached enormous proportions.

It is necessary to include in this hasty and incomplete analysis of advertising as an agency in distribution a reference to the character of the demand aroused by advertising. Advertising may be said to build up three general classes of demand: (1) expressed conscious demand, unexpressed conscious demand, and (3) subconscious demand.

The three classes may be illustrated by supposing a product for sale by grocers to be advertised in a periodical of large circulation by a double page costing for one insertion $\$ 8,000$. If as a result of the advertisement 30,000 people go to the grocery and buy the product, 60,000 plan to purchase the product at some future time when such an article is needed, and 100,000 more become open to a 


\section{MARKET DISTRIBUTION}

further exciting force, such as seeing the product at the grocery and recognizing it as one advertised, then we should call the 30,000 the expressed conscious demand, the 60,000 the unexpressed conscious demand, and the 100,000 the subconscious demand resulting from the advertisement. Expressed conscious demand means present sales; unexpressed conscious demand means future sales; subconscious demand means that the field has been fertilized so that future selling efforts will be more fruitful. Unexpressed conscious demand and subconscious demand are difficult of measure but must always be taken into account in any consideration of the efficiency of advertising as a selling agency.

\section{Purpose of Foregoing Analysis}

What has gone before has been by way of analysis. The general problem of distribution, the present day differentiation of products, the price policies open to the producer, the methods of sale, and the three chief selling agencies have all been subjected to hasty review. This has been rendered necessary by the fact that neither economists nor business men have previously made such an analysis.

Though what follows is by way of practical suggestion to the business man, the social significance of the problem must not be forgotten. While a 


\section{METHODS OF DISTRIBUTION}

more systematic handling of distribution problems means to the business man business success, a better organization of distribution means to society the prevention of an enormous annual waste. It is not alone that a considerable part of the billion dollars annually expended on advertising is wasted, that expenditures are often unwarranted and illdirected, and that the distributor often fails to take advantage of the demand aroused by making the goods physically available at the time and place they are wanted, but also that our cumbersome and chaotic system of distribution adds materially to the cost of goods to the consumer. It is to the costly and awkward machinery of distribution that the Tariff Board refers in its Summary of the Report on the Cotton Schedule, submitted to the President of the United States, March 22, 1912:" On account of more costly methods of distribution in this country from producer to consumer, the latter pays a decidedly higher retail price than the European consumer, even in the case of fabrics on which the cost of production and the mill price are as low here as there."

Nor is the social importance of improvements in distribution a matter merely of reducing the cost of products to the consumer. Our ill-organized system of distribution means that the consumer is not able readily and accurately to satisfy his needs. And this unfortunate condition is not inevitable. 


\section{MARKET DISTRIBUTION}

While it is true that up to this time the facts of distribution have not been gathered, described, and classified in such a way as fully to indicate tendencies and underlying principles, yet the way is open to a better organization. The business man must apply to the problems of distribution methods of systematic study that have been successful in other fields of human knowledge. There is an increasing need of scientific research methods in business. As business becomes more highly integrated, mere intuition must play a smaller part, and a scientific approach to the problems arising is demanded. And a scientific approach to the problems of distribution is feasible.

The ordinary business man today markets his product by rule of thumb. He gambles on his business instinct. The success or failure of a selling campaign is almost his sole source of knowledge as to whether his business instinct was a safe guide. If his past experience with other commodities has indicated that one agency or another of selling is more efficient, then he will adopt that agency for commodities which he subsequently attempts to market. If he compares the different agencies, it is through the average cost of selling by one or another agency. Thus if he finds over a short period that the average cost of selling a product through middlemen is less than the average cost of selling it through salesmen and adver- 


\section{METHODS OF DISTRIBUTION}

tising, he relies solely upon the former method. He does not wait to analyze the market as a basis for his consideration of the most economical agency. As an advocate of one particular method of selling, he does not always realize that an agency which is most economical for distribution in one section or stratum of the market may not be so in another. And least of all does he systematically test the ideas to be conveyed, and the very forms of expression, that are the basis of his selling efforts. 


\section{CHAPTER IV}

\section{CONSIDERATIONS OF THE MARKET}

The business man must first realize the intricacy of the problems he has to solve. He must analyze his market.' Enough has been said to indicate the complexity of the market problem. The business man faces a body of possible purchasers, widely distributed geographically, and showing wide extremes of purchasing power and felt needs. The effective demand of the individual consumer depends not alone upon his purchasing power but also upon his needs, conscious or latent, resulting from his education, character, habits, and economic and social environment. The market, therefore, splits up into economic and social strata, as well as into geographic sections.

The producer cannot disregard the geographic distribution of the consuming public. He may be able to sell profitably by salesmen where the population is dense, while such method of sale would be unprofitable in a region where there is a sparse population. If he bases a judgment upon the average cost of selling by salesmen for the whole market, he may easily go wrong, since the average might show that the use of such an agency was on 


\section{THE MARKET}

the whole profitable, although in some sections entering into the calculations the use of salesmen was actually unprofitable. Again, it might be economical for the distributor to establish his own branch stores in the denser urban centers, while in the sparsely populated regions he could most profitably distribute his product through the regular channels.

If, then, a sound system of distribution is to be established, the business man must realize that each distinct geographic section is a separate problem. The whole market breaks up into differing regions.

Equally important is a realization of what may be termed the market contour. The market, for the purposes of the distributor, is not a level plain. It is composed of differing economic and social strata. Seldom does the ordinary business man appreciate the market contour in reference to his product. Yet obviously the success of the producers of trade-marked hats depends upon a realization of this element of market contour. The distributor of a staple hat at $\$ 3.00$ appeals to different economic and social strata, faces different considerations, and finds different selling methods necessary, as compared with distributors selling a $\$ 5.00$ trade-marked hat, or those distributors selling $\$ 4.00$ or $\$ 6.00$ trade-marked hats. Differences in economic and social strata to be reached are as 


\section{MARKET DISTRIBUTION}

important as differences in geographic location and density, if a sound system of distribution is to be worked out.

Take the distributor who seeks to map out a selling campaign for a Catholic publication. It is essential that he take into account not merely the geographic distribution of the Catholic population in the United States, the regions where it is relatively dense, and the regions where it constitutes a small element in the population, but also he must take into account the distribution of that population through the economic strata of society. A method of distribution successful in New Orleans, where the Catholic population is dense and spread through all economic strata of society, might well fail if applied in Maine, where the Catholic population is relatively sparse and found mostly in the lower economic strata.

A careful analysis of his market, then, by areas and by strata, is the first task of the modern distributor.

Choice of Agencies in Distribution

Nor does the merchant-producer ordinarily realize how intricate is his problem as to the agency or combination of agencies that will be most efficient in reaching his market. As has been suggested above, the business man often adopts one method and becomes an advocate of it, dis- 


\section{THE MARKET}

regarding entirely other methods. While the method adopted may be more efficient than any other single method, it is apparent that a method which is relatively efficient in reaching one area may be inferior to another method in reaching another area. And so a system of distribution which has proved very effective in reaching one economic stratum may be relatively inefficient when employed to reach a different economic stratum in society.

The problem, then, of working out the most effective combination of agencies is a most complicated one. Each distinct area and economic stratum must be treated as a separate problem, and, moreover, the economic generalizations embodied in the law of diminishing returns must be taken into account in choosing that combination of selling agencies which will give, in the aggregate, the most efficient organization of the market.

Thus the distributor may find as he extends his operations in his immediate territory, geographically, that his selling cost steadily decreases, but that when he further extends his market the selling cost increases. He may find that in more distant areas selling by salesmen ceases to be profitable, and there he will perhaps establish a more economical system of selling by a combination of salesmen and circular letters. That is, he may reduce the number of visits by salesmen by one-half, and 


\section{MARKET DISTRIBUTION}

supplement their efforts by a series of circular letters or more personal correspondence. In even more distant areas, it may be necessary to eliminate the salesmen entirely and to sell only by direct advertising.

Perhaps enough has been said above, in analyzing the functions of the middleman and the extent to which the rise of functional middlemen has made alternative agencies of distribution possible, to free us from the necessity of here pointing out at length how complicated is the problem presented when the business man balances distribution through middlemen against direct selling through salesmen and advertising.

Attention must be called, however, to considerations that enter when one compares the use of salesmen with the use of different forms of advertising. The business man will often judge between different selling agencies solely upon the basis of the direct return over a short period. In discussing advertising we spoke of three classes of demand aroused by selling effort: (1) expressed conscious demand, (2) unexpressed conscious demand, and (3) subconscious demand. The direct and immediate return from selling efforts depends solely on expressed conscious demand. But the business man must take into account the unexpressed conscious demand and the subconscious demand. Suppose a smoking tobacco is advertised. A man 


\section{THE MARKET}

notices the advertisement, reads it, and decides that at some future time he will try it, and perhaps months later does so. This is not reflected in the direct immediate returns, yet clearly it is a result to be taken into account. Or suppose a man merely notices the advertisement. At a later date when purchasing tobacco, he is shown the advertised brand with other brands. The advertised brand being vaguely familiar to him from the advertisement, he purchases it in preference to the others. Here, too, the aroused demand would be of a degree not reflected in direct immediate returns, yet of value to the distributor.

It is obvious, then, that if one were balancing the advantages of selling through salesmen against selling through advertising in whole or in part, he should consider not only the expressed conscious demand reflected in the direct immediate returns but also the lesser degrees of demand which, while not immediately effective, tend to render subsequent selling easier.

Thus a salesman might make fifty calls at an expense of $\$ 100$, and ten sales might result from his efforts. Or for the same $\$ 100,5000$ pieces of direct advertising might be mailed, resulting perhaps in only eight sales. Or, perhaps, if the same $\$ 100$ were used for the insertion of a page advertisement in 100,000 of the circulation of a standard magazine, only six sales would result. Now it is 


\section{MARKET DISTRIBUTION}

apparent that judging by the direct results, the salesman is the most efficient agency of distribution, the direct advertising next, and the magazine advertising least efficient. But the distributor must bear in mind that there are grades of demand which do not become effective immediately, and must take into account that while the salesman made ten sales he had only forty opportunities to create these lesser grades of demand, while the direct advertising gave 4,992 opportunities for the creation of demand falling short of expression, and the magazine advertising, perhaps, 49,994 such opportunities, assuming for our present purpose that the advertisement was seen in one half the copies by one person. This is not an improbable supposition as each copy of a magazine is usually read by several persons.

A sound selling policy, then, must be built up on a careful analysis of the market by areas and strata, and upon a detailed study of the proper agency or combination of agencies to reach each area and stratum, taking into account always the economic generalizations expressed in the law of diminishing returns. It must also take into account not only the direct results obtained from the use of one or the other agency over a short period, but also the less measurable results represented by the unexpressed conscious demand and subconscious demand, which go to aid future selling campaigns. 


\section{THE MARKET}

All this tends rather to give a general sense of direction than to serve as a practical and tangible method of handling a specific problem of distribution. A clear grasp of the problem through a careful analysis is the first step in solving difficulties. To suggest any cure-all or even any panacea for the existing mal-adjustments in distribution, even were it possible, is not the purpose of this paper. The very complications revealed by analysis indicate the inadequacy of any single remedy. But it is possible to face the problem of remedy as well as of diagnosis in a scientific spirit, - to introduce what may be termed the "laboratory method."

\section{Laboratory Study of Distribution}

The crux of the distribution problem is the proper exercise of the selling function. The business man must convey to possible purchasers through one agency or another such ideas about the product as will create a maximum demand for it. This is the fundamental aim, whatever the agency employed. Hence this is the point where a scientific study of distribution must first be applied. How is the business man to determine what ideas are to be conveyed to the possible purchaser and what form of expression is best adapted to such conveyance?

Here, as elsewhere in distribution, the ordinary business man is today working by rule of thumb. He guesses at the suitable ideas and forms of expres- 


\section{MARKET DISTRIBUTION}

sion, and gambles on his guess. On the basis of his a priori selection of ideas fitted to build up a demand for his product and of a form of expression suited to convey the ideas effectively, he invests tens even hundreds of thousands of dollars in a selling campaign:

The more able business men, to be sure, seek to determine those facts about their goods that will attract the attention of the possible purchaser and awaken in him the desired reaction, that is, a desire for the article. They study in a general. way the points of superiority in quality and service possessed by their products as compared with other goods of like kind.

They also seek guides as to the form in which the ideas should be conveyed, in the general principles of style, all based on the fundamental notion of conserving the prospective purchaser's mental energy by cutting down the friction of communication. They know, for instance, that they should use short familiar words expressing their exact shade of meaning; that they should give preference to figurative language; that they should suggest a concrete image only after the materials of which it is to be made are conveyed; that they should avoid abstractions and generalizations where possible; that when they are suggesting the reaction desired their language should become quick, sharp, and compelling. 


\section{THE MARKET}

These things the more efficient business men know and apply. But all this is a priori. The need is for a method of practical test that will enable us to try out selling ideas and forms of expression, under laboratory conditions, as it were, before the investment of thousands and hundreds of thousands of dollars is staked on the success of the selling campaign.

Mention has been made of the annual expenditure of not less than a billion dollars in advertising. Unquestionably an extremely large percentage of this is wasted. This means not merely individual loss, but social loss. It is a diversion of capital and productive energy into unprofitable channels.

The causes of this waste are numerous. The commodity in question may be one not possessing those elements of quality and service which constitute the basis for a demand on the part of the consuming public. If the goods advertised are not adapted to satisfy a need, conscious or subconscious, of consumers, the advertising cannot be effective. Attempting to sell a thing that nobody needs is wasted effort.

Again, the medium used for the communication of the ideas about the goods may not be one that reaches the particular economic or social stratum in which possible purchasers of the commodity lie. Hence the ideas fail to create a demand because they do not reach those in whom a latent need for the commodity exists. 


\section{MARKET DISTRIBUTION}

Another important cause of advertising waste lies in the failure to take advantage of aroused demand. The distributor often fails to give proper attention to the matter of the physical supply of his product. There results a considerable leakage in demand from the inability of persons in whom a demand has been created to obtain the goods at the time when desired.

But the great cause of waste is probably the fact that the ideas about the goods, or the form in which those ideas are conveyed to possible purchasers, prove ill-adapted to secure the desired reaction, and thus to create in the consumer an effective demand.

If we can apply to this pressing problem of advertising waste methods of study which have proven efficient in other fields, the gain is clear. The engineer does not choose material for a bridge by building a bridge of the material and waiting to see whether it stands. He first tests the material in the laboratory. That is what the business man must do.

The statistician turns in his problems to the law of averages. He is familiar with what are termed mass phenomena. He knows that he can learn something of the average height of a body of people by studying the heights in a group of a few thousands of people drawn at random from the larger body. Provided that the smaller group is 


\section{THE MARKET}

so selected as to insure that it is typical of the larger body, and provided the group is large enough to render the law of averages applicable, the statistician knows when he has determined the average height of the smaller group that it will roughly coincide with the average height of the larger group.

This method of study can be applied by the business man in testing the ideas and forms of expression to be used in a selling campaign. In direct advertising, the mailing of selling letters, circulars or catalogues to prospective purchasers to draw from them an order for goods as an evidence of awakened demand, you have a stimulus and response adapted to direct statistical measurement. The number of responses per thousand communications can be determined. Here is the agency that the business man can employ in testing, under what are equivalent to laboratory conditions, the ideas and forms of expression that seem to him best adapted to awaken a demand for his product.

Suppose the manufacturer of a food product is planning a campaign to reach, not the consumer, but the grocers of the country. Now the whole body of dealers, large and small, handling groceries numbers something like 250,000. Let the distributor, after working out a set of ideas and forms of expression which seem to him likely to be effective in arousing the desired demand, test this material 


\section{MARKET DISTRIBUTION}

by mailing it to say 1,000 grocers. The group selected must be large enough to give typical results and it must be so selected as to be representative in character of the whole body of grocers.

Granting these elements, the distributor can determine the number of responses from the 1,000 grocers to whom the communication was sent, and can estimate from that result the average response per thousand of communications that would have been obtained if the same ideas in the same form of expression had been conveyed to the whole body of 250,000 dealers in groceries in the country. He can then test by means of direct mailing to another group of 1,000, a varying set of ideas or varying form of expression. And so on with other modifications of the selling material. Thus it will be possible to determine what ideas, in what arrangement and in what form of expression, are most effective to arouse the desired demand.

That the plan suggested is practical is indicated by the results of such an intensive study presented in Table I. Here are shown the results of "tests" and the results of complete mailings. The tests here covered only one stratum of society, a mailing list of bankers being used. The purpose of the selling material mailed was to obtain orders for certain publications. Various forms of " copy" were tested by mailing, usually to 500 names on the list. Where the return on any test exceeded 


\section{THE MARKET}

the mimimum standard of twenty orders per thousand communications the material was mailed to the complete list. In only one case did the complete mailing fail to show an average return per thousand communications substantially the

\section{BANKERS' TESTS}

Minimum Standard $=20$ Per M.

\begin{tabular}{|c|c|c|c|c|c|c|c|c|}
\hline \multirow[b]{2}{*}{$\underset{\text { Mailed }}{\text { Material }}$} & \multicolumn{4}{|c|}{ Tests } & \multicolumn{4}{|c|}{ Mailings } \\
\hline & Date & $\begin{array}{l}\text { No. of } \\
\text { pieces } \\
\text { mailed }\end{array}$ & $\begin{array}{c}\text { Total } \\
\text { orders } \\
\text { received }\end{array}$ & ${ }_{\text {M. }}^{\text {Nor }}$ & Date & $\begin{array}{l}\text { No. of } \\
\text { pieces } \\
\text { mailed }\end{array}$ & $\begin{array}{c}\text { Total } \\
\text { orders } \\
\text { received }\end{array}$ & ${ }_{\mathbf{M}^{\text {Ner }}}^{\text {Ner }}$ \\
\hline & 1909 & & & & 1909 & & & \\
\hline $\mathbf{A}^{1}$ & $3 / 30$ & 500 & 3 & 6 & & & & \\
\hline $\mathrm{A}^{2}$ & $3 / 30$ & 500 & 5 & 10 & & & & \\
\hline $\mathbf{B}^{1}$ & $8 / 13$ & 500 & 6 & 12 & & & & \\
\hline $\mathbf{B}^{2}$ & $9 / 13$ & 500 & 3 & 6 & & & & \\
\hline $\mathrm{C}^{1}$ & $9 / 15$ & 500 & 4 & 8 & & & & \\
\hline $\mathrm{C}^{2}$ & $9 / 15$ & 500 & 3 & 6 & & & & \\
\hline $\mathrm{D}^{1}$ & $9 / 15$ & 453 & $6)$ & & $0 / 017$ & 10049 & 260 & 18 \\
\hline $\mathrm{D}^{2}$ & $9 / 15$ & 500 & $18\}$ & 20 & $9 / 27$ & 19,943 & 300 & 18 \\
\hline $\mathbf{E}$ & $9 / 16$ & 500 & 7 & 14 & & & & \\
\hline $\mathrm{F}^{\mathrm{t}}$ & $9 / 21$ & 500 & $24)$ & & & & & \\
\hline $\mathrm{F}^{2}$ & $9 / 21$ & 500 & $12\}$ & 36 & $11 / 23$ & 10,511 & 589 & 35 \\
\hline $\mathbf{G}$ & $10 / 18$ & 1,000 & 30 & 30 & $11 / 28$ & 21,790 & 643 & 29.5 \\
\hline & & & & & 1910 & & & \\
\hline H & $11 / 16$ & 500 & 11 & 22 & $1 / 24$ & 6,554 & $165\}$ & 24 \\
\hline 11 & 1910 & 300 & 11 & $2 z$ & $1 / 24$ & 16,039 & $390\}$ & \\
\hline I & $4 / 11$ & 500 & $12\}$ & 94 & $5 / 5$ & 6,810 & $145\}$ & 95 \\
\hline & $4 / 11$ & 500 & $12\}$ & & $5 / 4$ & 12,154 & $336\}$ & 20 \\
\hline
\end{tabular}

Note. - Where the same letter appears with different exponents under " material mailed" it indicates that on the test mailing results were kept separately for the same material mailed to two small groups. 


\section{MARKET DISTRIBUTION}

same as that derived from the test mailing. In the case of Test $\mathrm{D}^{1}$, mailed September 15, 1909, the return is clearly out of proportion to the results from the mailing. The same material mailed on the same date, however, (Test $D^{2}$ ), gives for a similar small group a return much closer to the results obtained from the final mailing. When a minimum standard as low as twenty is used, and the test group numbers only 500, there is danger that the average will be disturbed as by one individual sending in several orders. The larger the test group the more exact an index will it give as to the results which will be obtained from a complete mailing.

This method of studying ideas and forms of expression in direct advertising would be important, even though its usefulness did not extend beyond direct advertising. It would permit one to guide a widely extended direct advertising campaign by an investigation relatively inexpensive.

But the importance of the method described does not end with direct advertising. Remember that the root idea is the same, whatever the agency for selling employed. Selling is accomplished by communicating to the possible purchaser ideas about the goods calculated to stimulate in him a desire for the goods. These ideas may be communicated through middlemen, salesmen, general advertising or direct advertising. Since the ideas 


\section{THE MARKET}

are the same, whatever the agency for communication, the business man can determine in his direct selling laboratory, what ideas and in what combination are the most effective selling material. $\mathrm{He}$ can then carry over into his selling by other agencies the knowledge there obtained.

Suppose an extensive campaign through periodicals is under consideration. The distributor contemplates spending perhaps hundreds of thousands of dollars upon advertising in certain periodicals. What can the "distribution laboratory" do to determine the ideas to be conveyed and the forms of expression to be used to create the desired demand? Now the circulation of a periodical to be used may run into the hundreds of thousands or even into the millions. The business man wishes to test the response that will result from the communication to this enormous body of subscribers of certain ideas expressed in certain forms. Not only can he work out the most effective ideas, the most effective arrangement, and the most effective forms of expression through the agency of direct mailing, but he can even test the final "copy" itself, just as it will appear in the periodical, by mailing it directly to relatively small groups.

Moreover, he can test the response to it found in differing strata of society. Ideas adapted to build up a demand for a commodity in one economic 


\section{MARKET DISTRIBUTION}

or social stratum may prove ineffective when dealing with another. The importance of this method lies in the fact that most periodicals circulate within certain fairly well-defined economic and social strata. The ideas and forms of expression that are most effective in one periodical hence may be relatively ineffective if used in another that reaches a different stratum.

Equally important is the application of the suggested method of study to selling through salesmen. The more progressive business men today train the salesmen in a certain basic " selling talk." That is, certain ideas, arranged in a certain order and expressed in certain forms are impressed upon them as likely to build up a demand for the article on the part of possible purchasers. The basic "selling talk" is not, of course, repeated parrot-like by the salesman, but it does serve as a foundation for his talks to possible buyers.

Here again the laboratory idea can be applied. The whole structure of the selling talk can be built up on the ideas, order of arrangement, and forms of expression established as the most efficient in creating demand through the medium of direct advertising. One need but appreciate the fundamental identity of the selling function, through whatever agency exercised, to realize that the results obtained in experiments in direct advertising can be carried over to selling by salesmen. 


\section{THE MARKET}

Note, too, that the general principles upon which the "testing" method depends, apply when we seek to study the possibilities of the whole market by the intensive cultivation of one section of it. A localized selling campaign, narrow in extent, will give relatively exact data from which the possibilities of a nation-wide campaign of like character may be judged. Obviously, if our law of averages holds good, we may carry over the results obtained in one section to other sections, and hence at small cost guide a widespread campaign.

The exact data that can be obtained through such " testing" methods permit a more scientific consideration of the decreasing returns obtained if one agency is used beyond a certain point. Hence a better combination of agencies is possible, with a view to the greatest aggregate efficiency.

\section{The Effect of .Different Price Policies}

When a business man contemplates putting a new product on the market, a serious problem is the price at which it shall be sold. In the introduction of a safety razor, for instance, at what price is it to be sold? In such a case the business man seeks to determine which price will give him the best net return, all things considered. Now the method of study developed above will permit the business man to determine by actual test 


\section{MARKET DISTRIBUTION}

the effective demand that can bebuilt up at different price levels in different economic and social strata. Hence he can fix the price on the basis of relatively exact data, rather than on a mere guess.

Again, the laboratory method here suggested lends itself to a determination of what elements of quality and service in a given product are deemed most essential by the consumer. The effectiveness of the ideas conveyed in building up a demand reflects the intensity of human wants as to the elements of quality and service described. The producer can sound the consumer and can better adapt his product to the consumer's felt needs.

Thus an entire selling campaign can be directed on the basis of what may be termed laboratory study. The empirical methods of the ordinary business man may be supplemented by scientific methods that have proven efficient in other fields.

The above practical suggestions have been directed primarily to the business man struggling with his immediate problems. Yet it may be well to emphasize once more the social importance of the suggestions. It is not merely that a large annual waste in advertising can be eliminated. Our whole system of distribution is in chaos. And the chaotic conditions in distribution mean that matter is ill-adjusted in form and place to human wants. Only as systematic and widespread study along the lines indicated is given to the problems of 


\section{THE MARKET}

distribution, can we build up an organized body of knowledge as to the facts and principles involved. And only on the basis of an organized body of knowledge about distribution can we hope to work out a more efficient organization of distribution.

And to this end the business man must coöperate with the scientist of the university. Much can be done by the trained student in his laboratory or in his study that will be of practical value in making possible a more efficient organization of distribution. The experimental psychologist can do much to work out general principles that will aid the business man in solving definite selling problems. The difficulty has been that the laboratory worker does not have the specific problems of the business man brought to his attention.

Similarly, the universities, through investigators trained in economics, can gather and correlate data upon distribution that will be of enormous practical value. They should, through research bureaus, study such problems as the cost of distribution in the various industries at different stages. And gradually a body of organized knowledge of the actual facts of business will arise. It is by development along such lines that future improvements in the system of distribution will be made possible. 



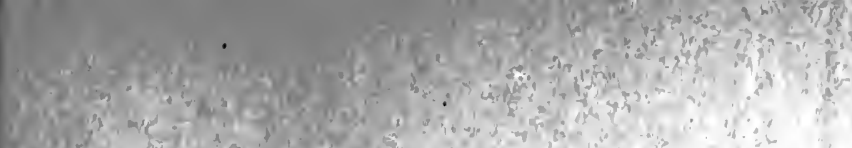

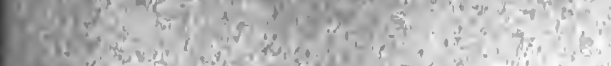

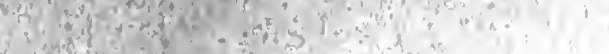

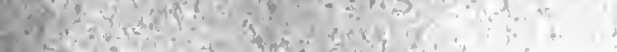

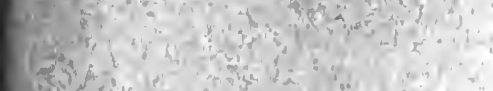

(1)

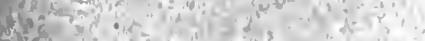

(4)

130

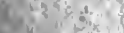

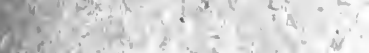

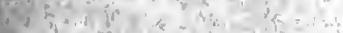

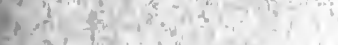

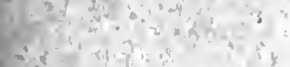

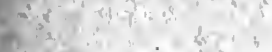

ento

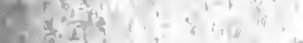

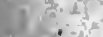

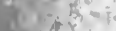

$-2,4=1$

- की

$-3 x^{\circ}$

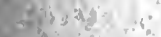

$=x^{4}, \frac{2}{2}$

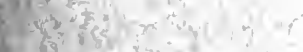

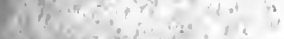

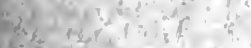

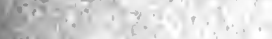

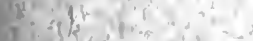

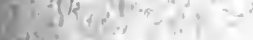

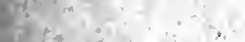

to

i. $=2 ;$

$0,1=2,0 \beta^{2}=$

(1)

Q

8.

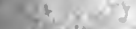

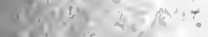

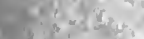

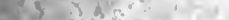

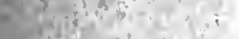

$=18=10$

$91-32$

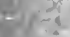

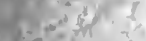

$=0$

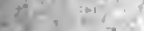

$2 x-3$

Wil tris?

all is atic

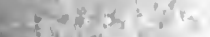

$x^{2}, \Rightarrow>v^{2}$

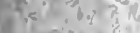

$w=1$ iो

Dinte of

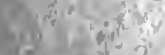

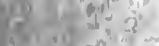




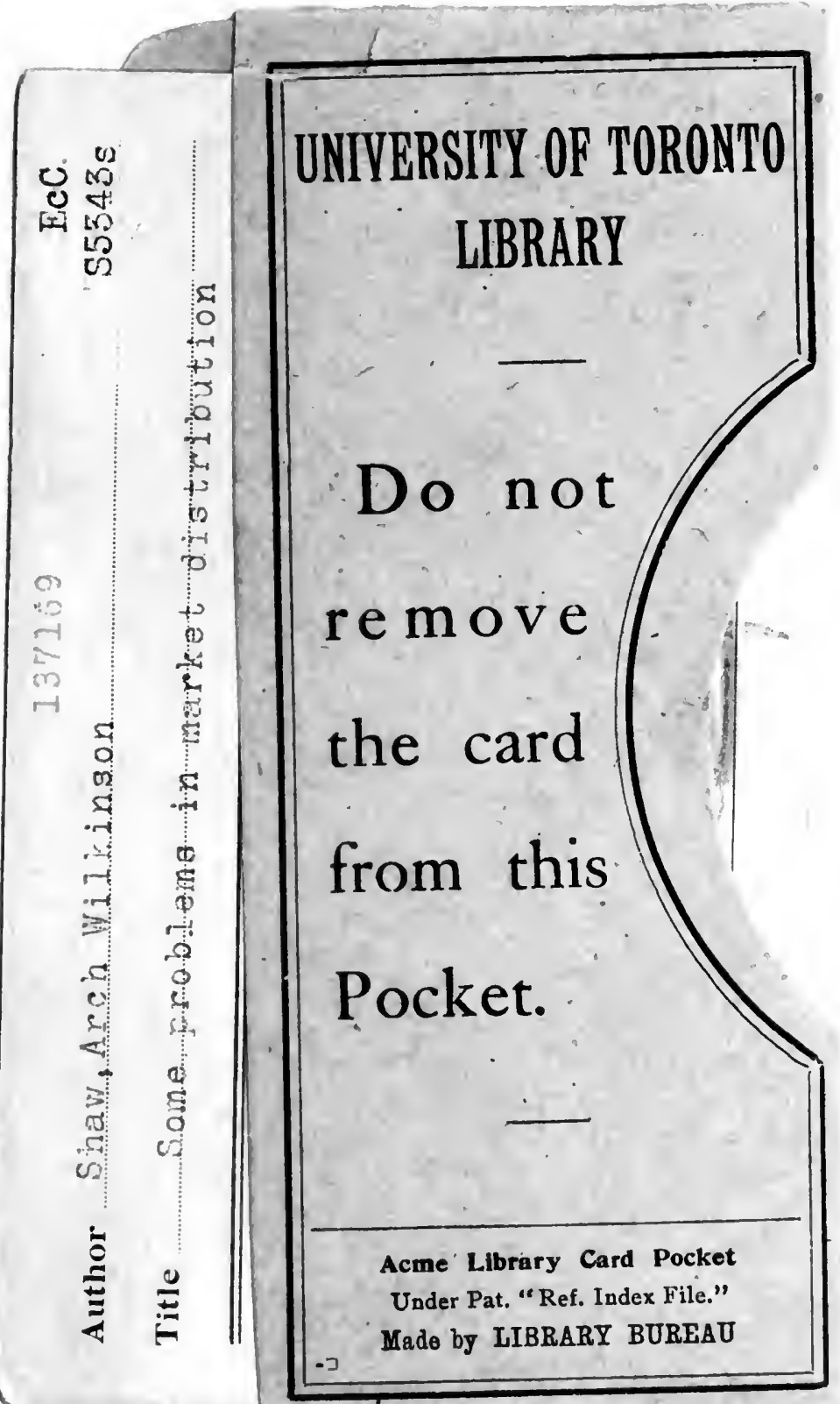


